\title{
Androgen receptor signaling inhibitors: post-chemotherapy, pre-chemotherapy and now in castration-sensitive prostate cancer
}

\author{
Nicholas Mitsiades ${ }^{1,2}$ and Salma Kaochar ${ }^{1}$ \\ 1Department of Medicine, Baylor College of Medicine, Houston, Texas, USA \\ 2Department of Molecular and Cellular Biology, Baylor College of Medicine, Houston, Texas, USA
}

Correspondence should be addressed to N Mitsiades or S Kaochar: mitsiade@bcm.edu or salma.kaochar@bcm.edu

This paper is part of a thematic review section celebrating 80 Years of Androgen Deprivation as a Treatment for Prostate Cancer. The guest editors for this section were Amina Zoubeidi and Paramita Ghosh.

\begin{abstract}
Based on pioneering work by Huggins, Hodges and others, hormonal therapies have been established as an effective approach for advanced prostate cancer (PC) for the past eight decades. However, it quickly became evident that androgen deprivation therapy (ADT) via surgical or medical castration accomplishes inadequate inhibition of the androgen receptor (AR) axis, with clinical resistance inevitably emerging due to adrenal and intratumoral sources of androgens and other mechanisms. Early efforts to augment ADT by adding adrenal-targeting agents (aminoglutethimide, ketoconazole) or AR antagonists (flutamide, bicalutamide, nilutamide, cyproterone) failed to achieve overall survival (OS) benefits, although they did exhibit some evidence of limited clinical activity. More recently, four new androgen receptor signaling inhibitors (ARSIs) successfully entered clinical practice. Specifically, the CYP17 inhibitor abiraterone acetate and the second generation AR antagonists (enzalutamide, apalutamide and darolutamide) achieved OS benefits for PC patients, confirmed the importance of reactivated AR signaling in castration-resistant PC and validated important concepts that had been proposed in the field several decades ago but had remained so far unproven, including adrenaltargeted therapy and combined androgen blockade. The past decade has seen steady advances toward more comprehensive AR axis targeting. Now the question is raised whether we have accomplished the maximum AR axis inhibition possible or there is still room for improvement. This review, marking the 80-year anniversary of ADT and 10-year anniversary of successful ARSIs, examines their current clinical use and discusses future directions, in particular combination regimens, to maximize their efficacy, delay emergence of resistance and improve patient outcomes.
\end{abstract}

\section{Key Words}

- prostate cancer

- androgen deprivation therapy

- androgen receptor (AR)

- abiraterone

- enzalutamide apalutamide

- darolutamide

\section{Introductory concepts and historical perspective}

The pioneering work of Huggins \& Hodges (1941), that we are celebrating in this issue of ERC (Zoubeidi \& Ghosh 2021), not only set the framework for the hormonal treatment of advanced prostate cancer (PC), but also was one of the first successful 'targeted' therapies for cancer in general. While most patients with advanced PC benefited 
from castration (androgen deprivation therapy (ADT)), resistance emerged quickly in most cases (within $1-3$ years, in general). This led to a series of important questions:

What are the mechanisms of resistance to first-line ADT?

Can a more comprehensive approach targeting all sources of androgenic stimulation delay emergence of resistance to ADT?

What is the best timing of the treatment intensification? Is earlier use of intensified ADT more effective? How early is early enough?

If deeper $\mathrm{AR}$ axis inhibition can accomplish better clinical outcomes, then how deep AR inhibition is enough to maximize the clinical benefit?

What are the mechanisms of resistance to the newer androgen receptor signaling inhibitors (ARSIs) and what is the next step in their use for improving outcomes for our patients?

Historically, the term ADT has been and still is used to refer only to suppression of production of testosterone by the testicular Leydig cells via surgical castration (bilateral orchiectomy) or medical castration (targeting the hypothalamic-testicular axis with GnRH analogs) (Mitsiades et al. 2011, Mitsiades 2013, Relugolix FDA Package Insert 2020). For the purposes of this article, we will refer to this regimen as 'standard ADT' (sADT). In PC patients receiving SADT, a circulating (peripheral) testosterone (circT) level of $<50 \mathrm{ng} / \mathrm{dL}$ has been and still is considered adequate testosterone suppression (Mitsiades et al. 2011, Relugolix FDA Package Insert 2020). When clinical progression would, inevitably, occur while maintaining circ $<<50 \mathrm{ng} / \mathrm{dL}$, it would be and still is defined as castration-resistant PC (CRPC).

However, several studies have reported that accomplishing stricter (lower) circT thresholds ( $<30 \mathrm{ng} / \mathrm{dL}$, $<25 \mathrm{ng} / \mathrm{dL}$, or even $<20 \mathrm{ng} / \mathrm{dL}$ ) was associated with even better clinical outcomes (Bertaglia et al. 2013, Wang et al. 2017, Ozyigit et al. 2019). The same was shown when circT was analyzed as a continuous variable (Perachino et al. 2010). Collectively, these results suggest that our ideal therapeutic goal should be to lower androgenic stimulation to as low as safely achievable. In further support, several mechanisms of PC cell resistance to ADT involve hypersensitization of the PC cells to (low levels of residual) androgens, for example, due to overexpression of AR mRNA and protein, frequently due to amplification at the AR gene locus (Visakorpi et al. 1995, Mitsiades et al. 2011, 2012, Mitsiades 2013, Quigley et al. 2018, Takeda et al. 2018, Viswanathan et al. 2018). Therefore, it is important to simultaneously suppress testosterone levels to the lowest level achievable and that goal requires comprehensive targeting of all sources of androgenic stimulation: gonadal, adrenal and intratumoral steroidogenesis (Mitsiades 2013).

In healthy adult men, $>95 \%$ of circT is of gonadal origin. The rest is synthesized either in the adrenals or in other, peripheral tissues (including the prostate gland and PC tissues). In situ ('intracrine') steroidogenesis can be de novo (with all enzymatic steps from cholesterol to testosterone and DHT happening in some PC tissues) or by conversion of weaker androgen precursors of adrenal origin: DHEA and androstenedione. DHEA, in the form of DHEA-sulfate, is the steroid with the highest circulating concentration in humans and thus, is an abundantly available precursor. Upon initiation of ADT, these extragonadal sources of androgens become very important for residual AR activation that allows for the survival of the PC cells, until other mechanisms of resistance make the cells completely resistant.

The importance of intratumoral steroid metabolism is highlighted by strong evidence that even well suppressed circT levels do not guarantee complete depletion of intratumoral androgens (Montgomery et al. 2008). In fact, intratumoral androgens and AR-dependent gene expression drop by a much lower degree compared to the degree of suppression of serum androgens after ADT (Mostaghel et al. 2007). Several steroidogenic enzymes are expressed in the prostate gland and in PC tissue (Montgomery et al. 2008) and can even be upregulated by androgen withdrawal (Mitsiades et al. 2012). For example, the mRNA levels of AKR1C3, an enzyme that can convert androstenedione to testosterone, are upregulated in PC cells within a few hours of androgen withdrawal (Mitsiades et al. 2012). Therefore, androgen deprivation triggers an acute adaptation feedback loop that enhances the ability of the PC cell to metabolize adrenal precursors into testosterone and DHT, thus sustaining tissue androgen levels and AR stimulation.

In essence, the term ADT has been used historically to describe, under the form of SADT, a now outdated hormonal therapy regimen that was inadequate androgen deprivation at the cellular level within the PC microenvironment, as intratumoral androgens actually persisted under these conditions (Montgomery et al. 2008). The PC field has since moved significantly forward with the addition of ARSIs to the ADT backbone. For the purposes of this review, we will focus our discussion on the newer, more effective ARSIs: specifically, the CYP17 inhibitor abiraterone and the second generation AR ligand-binding domain (LBD) antagonists (antiandrogens) enzalutamide, apalutamide 
and darolutamide, as these are the agents that have entered the market in recent years. Several names have been used to describe these regimens such as 'Intense Androgen Deprivation', 'intensified ADT', 'Comprehensive AR axis Targeting', 'augmented ADT', etc. The clinical successes of these combination regimens have led to substantial clinical benefits for PC patients, while validating the old hypotheses in the field about concurrently targeting all sources of androgenic stimulation, and redefining the use of ADT.

\section{Can a more comprehensive approach targeting all sources of androgenic stimulation delay emergence of resistance to ADT?}

\section{Historical review of older efforts}

Earlier efforts to target the androgenic contribution of extra-gonadal sources in CRPC go back several decades, with some clinical successes (some well-documented response rates and PFS benefits), but never established a definitive prolongation of overall survival (OS) via Phase III randomized controlled trials (RCTs) in the preabiraterone/enzalutamide era. As a result, while intriguing and sometimes widely used, these early approaches failed to gain level 1 evidence in their support.

\section{Earlier adrenal-targeted approaches}

Suppression of adrenal steroid production via surgical adrenalectomy or use of exogenous glucocorticoids in the past yielded some clinical successes (Storlie et al. 1995, Sartor et al. 1998, Kantoff et al. 1999, Nishimura et al. 2000, Fossa et al. 2001, Koutsilieris et al. 2001, Saika et al. 2001, Berry et al. 2002, Morioka et al. 2002, Tannock et al. 2004, Mitsiades et al. 2011) that have historical significance as proof-of-principle for the role of adrenal steroids in CRPC. Similarly, chemical adrenalectomy via the anticonvulsant aminoglutethimide or the antifungal ketoconazole (both are also non-specific inhibitors of several cytochrome $\mathrm{P} 450$ enzymes, including those involved in steroidogenesis) accomplished PSA responses in some patients (Small et al. 1997, Kruit et al. 2004, Peer et al. 2014) but the lack of an OS benefit in Phase III RCTs together with their significant toxicity (nausea, fatigue, edema, hepatotoxicity, neurotoxicity, rash, anorexia) and multiple interactions with other P450 substrate drugs prevented their formal FDA approval for this indication (Abratt et al. 2004, Small et al. 2004, Mitsiades et al. 2011).
However ketoconazole was widely used (off label) in CRPC and did serve as a forerunner of CYP17 inhibitors such as abiraterone.

\section{Earlier anti-androgens and 'combined androgen blockade'}

Another approach to target residual AR activation in ADTtreated patients is to directly displace the androgenic ligand from the AR, via a competitive ligand-binding domain (LBD) inhibitor (also called an anti-androgen). The first generation of such agents included flutamide, bicalutamide, nilutamide and cyproterone acetate (Chen et al. 2009, Mitsiades et al. 2011), which achieved PSA responses in some CRPC patients and gained popularity in this setting, but never definitively established an OS benefit for CRPC patients (Mitsiades et al. 2011). Moreover, they were extensively tested in the metastatic castration-sensitive PC (mCSPC) setting in combination with SADT under the concept of 'maximal' or 'combined androgen blockade' (Labrie et al. 1985), with a miniscule, at best, survival benefit (Klotz 2008, Mitsiades et al. 2011). One possible explanation for that overall failure was that these agents were not adequately potent AR antagonists, but rather partial agonists, and also prone to 'antagonist-to-agonist' conversion (Culig et al. 1999), an intellectually interesting (yet clinically detrimental) clinical phenomenon where the very hormonal treatment used was actually fueling the growth of the PC cells. This was first noticed due to clinical responses encountered in a subset of anti-androgen-treated CRPC patients (15-30\%) after withdrawal of the anti-androgen (Kelly \& Scher 1993, Leone et al. 2018) and was attributed to dysregulation of the AR complex via various types of somatically-acquired events, including:

AR LBD gain-of-function mutations such as T878A, W742C/L, H875Y and L702H (originally reported as T877A, W741C/L, H874Y and L701H, respectively) and others (Taplin et al. 1995, Marcelli et al. 2000, Hara et al. 2003, Yoshida et al. 2005, Chen et al. 2009, Gottlieb et al. 2012, Leone et al. 2018). (Note: A change in the current reference sequence of the androgen receptor cDNA (Gottlieb et al. 2012, McEwan \& Brinkmann 2016) led to a +2 shift in amino acid numbering between residues 78 and 449 and to $\mathrm{a}+1$ shift between residues 472 and 919 compared with the previously used, original reference sequence (M20132.1)).

- AR mRNA and protein overexpression, attributed to numerous mechanisms such as copy number gains (c) 2021 Society for Endocrinology Published by Bioscientifica Ltd. Printed in Great Britain 
of the $A R$ coding sequence and/or of an upstream enhancer, as well as changes in epigenetic and microRNA regulatory loops (Visakorpi et al. 1995, Chen et al. 2004, Mitsiades et al. 2012, Mitsiades 2013, He et al. 2014, Coarfa et al. 2016, Quigley et al. 2018, Takeda et al. 2018, Viswanathan et al. 2018).

Altered expression and recruitment of AR coactivators. for example, the p160 steroid receptor coactivators (SRCs) SRC-1, SRC-2 and SRC-3, also known as Nuclear Coactivators NCoA1, NCoA2 and NCoA3, are found to be overexpressed in advanced $\mathrm{PC}$ and, in particular, CRPC (Gregory et al. 2001, Agoulnik et al. 2005, 2006, Zhou et al. 2005, Taylor et al. 2010).

Overall, the first generation anti-androgens had suboptimal clinical performance with inadequate AR inhibitory activity and, while FDA-approved for use in PC, never achieved documented OS benefits in CRPC or as 'combined androgen blockade' in CSPC.

\section{Better drugs validate old concepts}

So were the concepts of adrenal-targeted therapy, antiandrogen use and combined androgen blockade flawed? No - they were just impeded by the availability of only suboptimal first generation agents with clear PD deficiencies. The field has significantly advanced due to emergence of:

(a) More selective enzymatic inhibitors of androgen synthesis that are better-tolerated and more effective. Specifically, the CYP17 inhibitor abiraterone (CB7598) is a potent inhibitor of androgen biosynthesis. CYP17 (steroid 17-alpha-hydroxylase/17,20 lyase; gene name CYP17A1) has two enzymatic activities: 17-hydroxylase (necessary for the synthesis of both androgens and glucocorticoids) and 17,20 lyase (necessary for the synthesis of androgens only). Abiraterone inhibits both activities. Consequently, in the absence of glucocorticoid supplementation, abiraterone raises serum ACTH levels and increases adrenal conversion of cholesterol to pregnenolone, progesterone and mineralocorticoids (which do not require CYP17). The mineralocorticoid excess can cause fluid retention, edema, hypertension and hypokalemia, while progesterone can function as a non-canonical AR agonist (especially in the case of LBD-mutant AR) and as a canonical PR agonist, both of which can drive resistance to abiraterone (Cai et al. 2011, Chen et al. 2015a). For that reason, abirateronetreated patients are also given replacement doses of prednisone or prednisolone $(\mathrm{P})$, in order to decrease the risk of mineralocorticoid side-effects and to enhance anticancer activity (Danila et al. 2010, Bedoya $\&$ Mitsiades 2013).

Because abiraterone has poor oral absorption and is susceptible to hydrolysis by esterases, abiraterone acetate (AA, CB7630) was developed as an orally bioavailable, esterase-resistant prodrug (Ryan \& Cheng 2013). Abiraterone is at least 10-times more potent as an inhibitor of CYP17 than ketoconazole (Haidar et al. 2003) and more selective, hence better tolerated. Not surprisingly, several studies have shown that $\mathrm{AA}+\mathrm{P}$ is more effective than ketoconazole (Peer et al. 2014) and still somewhat effective even in ketoconazole-resistant CRPC (Danila et al. 2010, Kim et al. 2014). It deserves to be noted that there are additional proposed mechanisms of action for the anticancer activity of abiraterone, including direct antagonism of AR (Richards et al. 2012, Norris et al. 2017).

(b) Second generation orally bioavailable anti-androgens (enzalutamide, apalutamide and darolutamide) with improved PD properties: As mentioned above, flutamide, bicalutamide, nilutamide and cyproterone are prone to 'antagonist-to-agonist' conversion in PC cells due to overexpression of AR or its coactivators, somatic AR mutations, or other mechanisms (Mitsiades et al. 2011). For that reason, a library of nonsteroidal anti-androgens were rationally optimized for inhibition of AR transcriptional activity based on the AR crystal structure and were screened to select for lack of agonistic activity (Tran et al. 2009). The lead compound MDV3100 (enzalutamide) and the related ARN-509 (apalutamide) were reported to bind AR with higher affinity than bicalutamide, prevent its nuclear translocation and DNA binding, and have anticancer activity in preclinical in vitro and in vivo models without incurring agonistic activity (Tran et al. 2009, Scher et al. 2010, Clegg et al. 2012, Rathkopf \& Scher 2013). The phase 1-2 study of enzalutamide documented antitumor effects at all doses used (Scher et al. 2010) and set the stage for its rapid entry into Phase III testing and FDA approval. In agreement with its higher inhibitory activity and lower propensity for 'antagonist-to-agonist' conversion, anti-androgen withdrawal responses after discontinuing enzalutamide, although possible, are significantly less common and less durable than what was encountered with first generation anti-androgens (Phillips 2014, Schrader et al. 2014, von Klot et al. 2014a, von Klot et al. 2014b, Rodriguez-Vida et al. 2015, (c) 2021 Society for Endocrinology Published by Bioscientifica Ltd. Printed in Great Britain 
Poole et al. 2017, Leone et al. 2018). Still, the AR F877L (previously F876L) mutation has been reported to confer an antagonist-to-agonist switch to enzalutamide and apalutamide that drives resistance (Balbas et al. 2013, Joseph et al. 2013, Korpal et al. 2013).

More recently, darolutamide (ODM-201, BAY-1841788), an AR antagonist with a distinct chemical structure, was introduced to the clinic and approved for the treatment of patients with non-metastatic castration-resistant PC (nmCRPC) (Fizazi et al. 2019, 2020). Some preclinical experiments indicate that darolutamide is active against LBD-mutant ARs that confer resistance to enzalutamide and apalutamide such as AR F877L (previously F876L) and $\mathrm{W} 742 \mathrm{C} / \mathrm{L}$ (previously $\mathrm{W} 741 \mathrm{C} / \mathrm{L}$ ), but that remains to be confirmed in the clinic (Sugawara et al. 2019). Darolutamide is reported to exhibit negligible bloodbrain barrier (BRB) penetration, which may explain why, contrary to enzalutamide, its trials show that it does not significantly increase the risk of seizures, falls, or fractures (Moilanen et al. 2015, Shore 2017, Sugawara et al. 2019).

\section{Novel ARSIs find their place in PC treatment}

Early phase II studies of abiraterone (Danila et al. 2010, Reidetal.2010) and enzalutamide(Scher etal.2010)provided proof of principle that these are active agents in CRPC and established that the term 'androgen-independent' PC, in the way that it had been used until those studies, was actually a misnomer. The same Phase II studies provided evidence that abiraterone and enzalutamide are active even in CRPC patients previously treated with older agents such as ketoconazole or bicalutamide, although in some cases with somewhat lower response rate (Danila et al. 2010). As a result, subsequent studies generally excluded patients with prior exposure to any ARSI of any generation in order to avoid cross-resistance. In these Phase III studies, both abiraterone and enzalutamide had substantial OS benefits and PSA response rates in mCRPC patients, both in the post-chemotherapy and pre-chemotherapy settings (Table 1 ), and that led to their approval, first for chemotherapyrefractory mCRPC and, soon afterwards, for chemotherapynaïve mCRPC. Subsequent results from Phase III studies established the efficacy of abiraterone and enzalutamide in earlier disease states, namely non-metastatic (M0) CRPC and mCSPC. Apalutamide and darolutamide, which entered clinical development a few years after abiraterone and enzalutamide, were examined directly in these earlier disease states, as their administration to CRPC patients who had already received enzalutamide (or even abiraterone) would likely mask their clinical efficacy. Based on these clinical trials (timeline presented in Table 1), the current status of regulatory approval at the time of this writing (February 2021) is:

- $\quad \mathrm{AA}+\mathrm{P}$ is approved for the treatment of patients with metastatic castration-resistant PC (mCRPC) and metastatic high-risk castration-sensitive PC (CSPC).

- $\quad$ Enzalutamide is approved for the treatment of patients with CRPC (irrespective of metastatic or not status) and metastatic CSPC (mCSPC), irrespective of risk stratification.

- $\quad$ Apalutamide is approved for the treatment of patients with mCSPC, irrespective of risk stratification, and non-metastatic CRPC (nmCRPC).

- Darolutamide is approved for the treatment of patients with nmCRPC.

- $\quad$ Ongoing clinical trials are examining the role of ARSIs in earlier disease states such as enhancing neoadjuvant sADT prior to prostatectomy (e.g. https://clinicaltrials. gov/ct2/show/NCT03080116, https://clinicaltrials. gov/ct2/show/NCT03767244).

\section{Conclusions from the ARSI clinical trials and thoughts on augmenting frontline ADT}

Deeper AR axis inhibition accomplished better outcomes: It is clear that the concepts of adrenaltargeted therapy, anti-androgen use, and combined androgen blockade were correct but were previously impeded by the lack of good pharmacological agents. These newer ARSIs have validated the old concepts because they have superior PD and PK properties. In addition to the overall success of the newer ARSIs (which far eclipses any efficacy the older agents such as first generation anti-androgens and ketoconazole had ever shown), head-to-head comparison trials (TERRAIN (Shore et al. 2016), STRIVE (Penson et al. 2016)) have also confirmed that enzalutamide is clearly superior to bicalutamide and, consequently, has almost completely replaced it in the clinic (although still included as an option in the National Comprehensive Cancer Network guidelines). Similarly, the use of ketoconazole in PC has essentially been completely replaced by $\mathrm{AA}+\mathrm{P}$ (although still included as an option in the National Comprehensive Cancer Network guidelines).

- Direct comparison of the absolute clinical benefit between these studies is hindered by the differences 


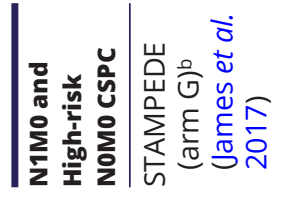

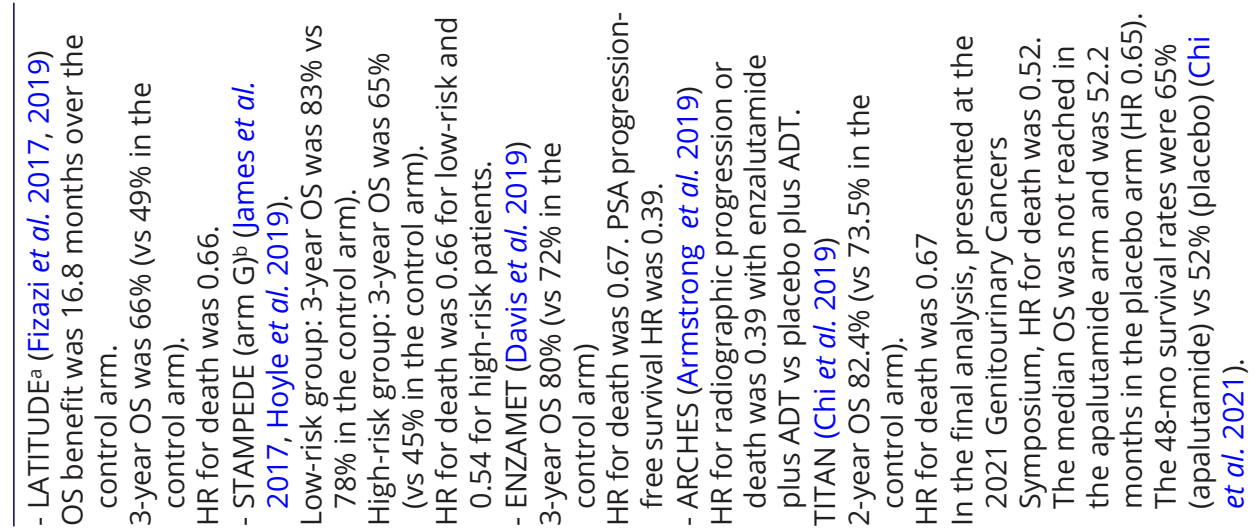
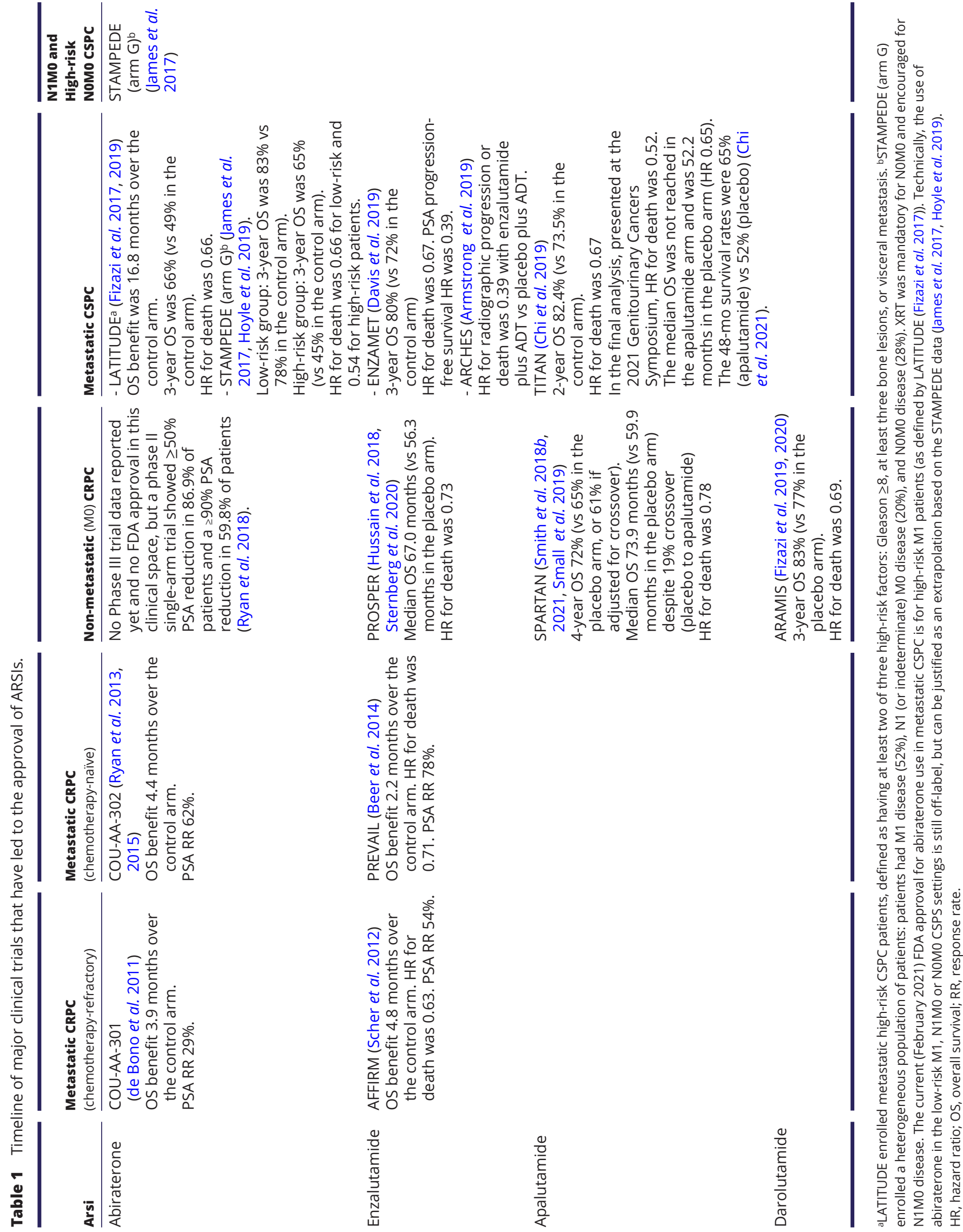
between study populations and trial designs, and can only be considered hypothesis-generating. With those caveats in mind, one could notice that all four ARSIs are biologically active and no particular pattern of superiority emerges from the results of the studies in Table 1. PSA response rates tend to be slightly numerically higher with enzalutamide than with $\mathrm{AA}+\mathrm{P}$, but this does not appear to translate into longer survival benefits. As of February 2021, enzalutamide has the broadest approval for use in all states of CRPC (irrespective of metastatic status and prior chemotherapy use) and metastatic CSPC. The current approval for AA+P covers only metastatic CRPC and metastatic high-risk (as defined by the LATITUDE criteria (Fizazi et al. 2017)) CSPC. However, arm $\mathrm{G}$ of the STAMPEDE trial $(\mathrm{AA}+\mathrm{P})$ also enrolled patients with low-risk metastatic CSPC or lymph-node positive PC or non-metastatic PC receiving ADT. From this heterogeneous study arm, in our clinical practice $(\mathrm{NM})$ we frequently extrapolate and extend, off label, the use of AA+P to intensify ADT used in the lowrisk M1 or N1M0 or NOM0 CSPS settings.

More significantly, it is our opinion that the differences in the approved indications between the four ARSIs in Table 1 simply reflect strategic decisions of the respective manufacturers to prioritize positioning of each drug in certain clinical spaces, rather than actual differences in clinical activity. The approved indications for all ARSIs are very likely to continue expanding in the near future, based on emerging data from ongoing and future clinical trials. For example, $\mathrm{AA}+\mathrm{P}$ does not (yet) have FDA approval for use in non-metastatic (M0) CRPC, but this is only due to lack of reported Phase III clinical trial data, and it has actually shown promising Phase II data (Ryan et al. 2018). Similarly, apalutamide and darolutamide would be expected to be active in an ARSI-naïve, chemotherapy-refractory metastatic CRPC patient, but such patients should be uncommon now that four ARSIs carry approved indications for much earlier disease states and, therefore, such a clinical trial would be both very difficult to accrue and practically irrelevant for real-world clinical care. Thus, lack of data supporting activity in that clinical space does not mean lack of activity in that space.

\section{Timing of the intensification}

The use of ARSIs in pre-chemotherapy mCRPC is not substantially more effective than their use in postchemotherapy mCRPC (the PSA response rates are numerically higher in the pre-chemotherapy setting, but the OS benefits are not). However, the use of ARSIs in mCSPC or nmCRPC is substantially more effective than use in the mCRPC state. For example, the improvement in median OS upon addition of $\mathrm{AA}+\mathrm{P}$ to $\mathrm{SADT}$ in $\mathrm{mCRPC}$ patients is about 4 months (irrespective of prior chemotherapy use), but four timesasmuchin mCSPCpatients. Similarly, theimprovement in median OS with the addition of enzalutamide to SADT is far more substantial in nmCRPC than in mCRPC patients. That suggests that initiating an ARSI earlier (before establishment of metastatic CRPC or before emergence of clinical metastasis) is associated with substantially better clinical outcomes. Data from the addition of an ARSI to SADT in the nmCSPC state is not yet available, but it would be very interesting to know if the clinical benefits will be even higher in that even earlier disease state.

Why does the combination of an(y) ARSI with sADT work better if started earlier? One possible explanation is that, because several mechanisms of resistance overlap between sADT and ARSIs, implementing more comprehensive AR axis inhibition earlier prevents the emergence of resistant clones (Mitsiades 2013). Several studies examining the significance of the PSA nadir on ADT support this hypothesis. The SWOG Trial 9346 (INT-0162) showed that the absolute PSA value after ADT is a strong independent predictor of survival in MPC (Hussain et al. 2006). Specifically, median survival was 13 months for patients with a PSA of more than $4 \mathrm{ng} / \mathrm{mL}$ after 7 months of ADT, 44 months for patients with PSA of more than $0.2-4 \mathrm{ng} / \mathrm{mL}$ after seven months of ADT, and 75 months for patients with PSA of $0.2 \mathrm{ng} / \mathrm{mL}$ or less after seven months of ADT. In a subsequent SWOG study, metastatic PC patients with a suboptimal response to ADT (PSA > 4.0 $\mathrm{ng} / \mathrm{mL}$ after 6-12 months of ADT) had their hormonal regimen augmented with $\mathrm{AA}+\mathrm{P}$. However, only five of 40 participants (13\%) patients achieved a PSA level of $\leq 0.2$ $\mathrm{ng} / \mathrm{mL}$, while 13 (33\%) additional patients achieved a reduction in the PSA level to $<4.0 \mathrm{ng} / \mathrm{mL}$ but $>0.2 \mathrm{ng} / \mathrm{mL}$ (Flaig et al. 2017). A cumulative PSA response rate of $45 \%$ in this small study may not be statistically different from what was seen in COU-AA-302 (Ryan et al. 2013, 2015), but overall, this study failed to reach its predefined endpoint, and was considered as evidence that ADT intensification after castration-resistance has emerged in metastatic PC may be too late for optimal efficacy.

\section{Optimal ARSI sequencing and cross-resistance}

All major clinical trials that led to the clinical development, registration, and FDA approval of each ARSI (Table 1) 
excluded patients who had been significantly exposed to any other ARSI (including older generation agents such as ketoconazole, aminoglutethimide, etc.) in order to avoid contamination by cross-resistance. As a result, all ARSIs entered the market based only on data from 'ideal cases' of patients who were naïve to all other ARSIs and without any studies directly comparing ('head-to-head') the activity of different ARSIs or examining cross-resistance between them. As pointed out in the previous section, the informal numerical comparison of the response rates and OS benefits seen in these registration trials (interpreted with caution, as the use of different study populations and trial designs prohibits a formal comparison), do not highlight any particular ARSI as substantially superior to the others (enzalutamide tends to give numerically higher PSA response rates than abiraterone, but this does not appear to translate into longer survival benefits). Moreover, a prospective study that randomized mCRPC patients to first-line abiraterone $(+\mathrm{P})$ or enzalutamide for a head-tohead comparison found no significant difference between the two ARSIs in time to PSA progression, even though PSA responses were more common in the enzalutamide cohort (Khalaf et al. 2019).

After FDA approval of these agents and general use in real-world practice, it became a common experience that the clinical responses to either abiraterone $(+\mathrm{P})$ or enzalutamide as second-line ARSIs after progression on the other agent are, at best, modest (PSA response rates in the range of 2-36\%) and not durable (Loriot et al. 2013, Noonan et al. 2013, Bianchini et al. 2014, Azad et al. 2015a, Attard etal. 2018, de Bono etal. 2018, Khalaf etal. 2019). This cross-resistance between these two classes of ARSIs is not surprising, as several mechanisms can provide resistance to both CYP17 inhibitors and 2nd generation antiandrogens. Such mechanisms include constitutively active AR variants (including ARv7), and treatment-associated NEPC transdifferentiation (see section on 'Mechanisms of resistance to ARSIs'). Nevertheless, crossover from one ARSI to another is used frequently in the clinic, especially as it is more appealing to use another hormonal agent instead of cytotoxic chemotherapy.

In that scenario, the question arises regarding the optimal sequencing of the ARSIs: The same study of mCRPC patients by Khalaf et al. found that the abiraterone $(+\mathrm{P}) \rightarrow$ enzalutamide sequence may be associated with longer time to second PSA progression and higher PSA response rates on second-line ARSI therapy compared to the inverse sequence (Khalaf et al. 2019). A systematic review and meta-analysis of 10 crossover studies confirmed that the abiraterone $(+\mathrm{P}) \rightarrow$ enzalutamide sequence was significantly associated with better PFS than with the opposite treatment sequence, but the OS barely missed statistical significance (pooled HR: 0.77, 95\% CI: 0.59-1.01, $P=0.055$ ) (Mori et al. 2020). Thus, it is possible that using abiraterone acetate followed by enzalutamide may provide the maximum possible benefit, at least as far as PFS. Other factors that may affect clinical decision making in selecting which ARSI to use first are the adverse event profile of each agent (Table 2) and cost (abiraterone is already generic in the US, while the three second generation anti-androgens are not). The use of biomarkers in this setting remains to be explored. For example, it is plausible but remains to be established whether ARv7-negative status after progression to the first ARSI agent would accurately predict sensitivity to a second ARSI agent.

Again, it should be noted that irrespective of the sequencing of these ARSIs, the response to whichever agent is used as a second-line ARSI is short-lived. In our own clinical practice $(\mathrm{N} \mathrm{M})$, after progression on an ARSI, we stratify patients based on severity of symptoms and urgency of the need for a clinical response at that point. We offer the option of a second ARSI agent in sequence after progression on the first ARSI agent only for those CRPC patients who are generally asymptomatic and are not at imminent risk of harm from delaying active therapy. In metastatic CRPC patients who, after progression on the first ARSI agent, are symptomatic or at high risk for a skeletal event, visceral crisis or other major complication, we strongly recommend cytotoxic chemotherapy (taxane). This is supported by the results of the CARD trial, where patients who had progressed on abiraterone or enzalutamide received the other ARSI or cabazitaxel, with cabazitaxel showing superior progression-free survival and overall survival (de Wit et al. 2019).

\section{Depth of AR axis inhibition: how much is optimal?}

With the (long overdue) success of combining two hormonal agents (sADT+ one ARSI), have we reached the maximum potential benefit or is there room for further improvement in our hormonal regimens for PC? If the addition of an ARSI to sADT improves clinical outcomes (two hormonal agents in combination work better than one), then one could hypothesize that the combination of three hormonal agents (SADT to suppress testicular androgen production + CYP17 inhibitor to suppress 
adrenal steroidogenesis + anti-androgen to block binding of any escaping/residual androgen to the AR) might target that AR axis more comprehensively, overcoming more putative mechanisms of resistance and might yield even better clinical results. Unfortunately, this has not been the case so far:

(1) Adding the second ARSI after progression to the first ARSI in CRPC patients: The randomized PLATO study examined whether, in the setting of enzalutamide resistance in $\mathrm{mCRPC}$, the addition of $\mathrm{AA}+\mathrm{P}$ to continuous enzalutamide use would be superior to switching to $\mathrm{AA}+\mathrm{P}$ (plus placebo). Unfortunately, there was no difference in PFS between the groups, and the PSA response rates were very low (1\% for the combination group that received the two ARSIs concurrently and $2 \%$ for the sequential treatment group that switched from enzalutamide to $\mathrm{AA}+\mathrm{P}$ (Attard et al. 2018)).

(2) Combining two ARSIs with ADT in ARSI-naïve CRPC: The phase III trial Alliance A031201 (NCT01949337) examined whether the addition of $\mathrm{AA}+\mathrm{P}$ to enzalutamide would be superior to enzalutamide monotherapy in men with ARSI-naïve mCRPC. Unfortunately, the study showed no advantage for the combination of the 2 ARSIs over enzalutamide alone. Grade $3-5$ adverse events occurred in $55.6 \%$ and $68.8 \%$ of patients taking enzalutamide and enzalutamide/ abiraterone/prednisone, respectively. Treatment discontinuation (12\% vs 5\%) and patient withdrawal rates $(13 \%$ vs $5 \%)$ were higher in the combination group due to adverse events. Another trial (ACIS) examined a similar concept, using apalutamide instead of enzalutamide. Again, the combination of apalutamide+abiraterone/prednisone did not improve OS compared to abiraterone/prednisone in mCRPC (Rathkopf et al. 2021). The combination of enzalutamide with abiraterone and SADT has also been undergoing testing since July 2014 as arm J of the STAMPEDE trial (NCT00268476) (Attard et al. 2014).

(3) Using two ARSIs+ADT in the neoadjuvant setting: The neoadjuvant setting allows to rapidly assess the anticancer activity of a systemic therapy, examine possible biomarkers of response, and dissect mechanistic hypotheses. Neoadjuvant systemic therapy is now commonly used in early breast cancer and the achievement of pathologic complete response (pCR) has been proposed as a surrogate endpoint for OS. On the contrary, despite significant efforts, neoadjuvant systemic therapy (including hormonal therapy) is still not considered a standard-of-care approach for localized/locally advanced PCs prior to prostatectomy and was never able to improve diseasefree survival (DFS) and overall survival (OS). It is possible that SADT cannot adequately suppress the AR axis inside the PC cells in order to achieve pCR. Indeed, in a randomized phase II trial, the addition of $\mathrm{AA}+\mathrm{P}$ to ADT resulted in more effective suppression of intraprostatic androgens than ADT alone (Taplin et al. 2014). Still, in the same study, even after 24 weeks of neoadjuvant hormonal therapy with $\mathrm{ADT}+\mathrm{AA}+\mathrm{P}$, the pCR rate was only $10 \%$. For that reason, a follow-up study examined whether the combination of neoadjuvant $\mathrm{ADT}+$ enzalutamide $+\mathrm{AA}+\mathrm{P}$ would be more effective than ADT + enzalutamide for 6 months before radical prostatectomy in men with locally advanced PC (McKay et al. 2019). Unfortunately, the pCR rate was only 10 and $8 \%$ in the two groups, respectively. In addition, more intense hormonal therapy was not associated with better outcomes as far as surgical margin positivity, extracapsular extension, or seminal vesicle invasion, although it showed a non-statistically significant trend for more minimal residual disease (less than $5 \mathrm{~mm}$ ). In agreement, in another phase II neoadjuvant study of six months ADT+apalutamide with or without abiraterone in localized high-risk PC, dual ARSI treatment did not result in better outcomes at the time of prostatectomy (Efstathiou et al. 2020).

In summary, so far the clinical evidence suggests that combining more than one ARSI with ADT is not beneficial. This may sound counterintuitive at first, and a mechanism to explain it has not been established. It is possible that the combination of ADT with one ARSI (either AA+P or second generation anti-androgen) may have already brought $\mathrm{AR}$ axis activation to its nadir, and there is no more additional benefit from the third agent. Another point to consider is that AA must be administered together with glucocorticoids (albeit at replacement doses) and glucocorticoids are known to drive resistance to second generation antiandrogens via GR (see section on 'Mechanisms of resistance to ARSIs'); therefore, perhaps this combination is flawed at its inception. Finally, a more complex hypothesis comes from an interesting study that suggests that, while originally considered a pure AR antagonist, enzalutamide may function as a partial agonist that reprograms $A R$ binding from canonical AREs to a distinct DNA motif and to a different set of genes that promote CRPC growth (Chen et al. 2015b). The pioneer transcription factor GATA2 may play a role in this switch (Yuan et al. 2019) and 
Table 2 Reported Adverse Events of ARSIs, from Abiraterone FDA Package Insert (2020), Apalutamide FDA Package Insert (2020), Enzalutamide FDA Package Insert (2020), Darolutamide FDA Package Insert (2021).

\begin{tabular}{l} 
Abiraterone \\
\hline Hypertension, hypokalemia, \\
edema, due to \\
mineralocorticoid excess. \\
Liver toxicity, fatigue. Need \\
for glucocorticoid \\
replacement (concern for \\
diabetics, etc.).
\end{tabular}

Apalutamide
Risk of seizure (0.4\% across
all patients).
Musculoskeletal pain and
arthralgias, decreased
neutrophil count.
Falls and fractures.
Hyperglycemia and
hypertriglyceridemia.
No need for glucocorticoid
replacement (actually,
discouraged as it may drive
resistance).

\section{Darolutamide}

Reportedly not crossing the blood-brain barrier, so it does not significantly increase risk of seizures or falls.

Fatigue, decreased neutrophil count, transaminitis, hyperbilirubinemia.

No need for glucocorticoid
replacement (actually,
discouraged as it may drive
resistance).

both androgen deprivation and enzalutamide are known to increase the levels of GATA2 in PC cells (He et al. 2014). Thus, one can propose that in patients treated with ADT alone (testicular androgen suppression only), adrenal and intratumoral steroidogenesis results in substantial tissue DHT levels that drive AR signaling and can be antagonized by enzalutamide (hence explaining the significant clinical benefit of adding enzalulamide to SADT in CSPC and $\mathrm{CRPC}$ ), while in patients receiving $\mathrm{ADT}+\mathrm{AA}+\mathrm{P}$ the intratumoral androgen levels have already been suppressed so low that now the dominant effect of enzalutamide is its GATA2-mediated agonistic effect on AR. Certainly, this hypothesis remains to be proven in the clinic, and the development of a GATA2 inhibitory approach would be one way to examine whether it can overcome the agonistic activity of enzalutamide (as a quadruple therapy of ADT+2 ARSIs + GATA2 inhibitor).

\section{Mechanisms of resistance to ARSIs}

Several mechanisms of resistance to ARSIs have been proposed (Vlachostergios et al. 2017), including:

(a) Reactivation of the AR transcriptional program via alterations in AR itself such as

- $\quad$ AR mRNA and protein overexpression. AR represses its own mRNA expression, and profound AR inhibition leads to adaptive derepression of its expression. Additionally, amplification events in the $A R$ gene locus (involving the gene body and/or upstream enhancer sequences) are common in CRPC, in particular ARSIresistant CRPC (Visakorpi et al. 1995, Waltering et al. 2009, Grasso et al. 2012, Mitsiades et al. 2012, He et al.
2014, Azad et al. 2015b, Romanel et al. 2015, Foley \& Mitsiades 2016, Quigley et al. 2018, Takeda et al. 2018, Viswanathan et al. 2018).

AR LBD mutations that restore AR activity in the presence of ARSI (Balk 2002, Steinkamp et al. 2009, Gottlieb et al. 2012, Azad et al. 2015b, Wyatt et al. 2016, Steinestel et al. 2019). The AR F877L (previously F876L) mutation has been reported to confer an antagonistto-agonist switch to enzalutamide and apalutamide that drives resistance (Balbas et al. 2013, Joseph et al. 2013, Korpal et al. 2013). It needs to be examined clinically whether darolutamide can overcome that resistance, as has been proposed based on in vitro studies (Sugawara et al. 2019).

- Constitutively active, truncated AR splice variants that lack part of or the entire LBD and function in a ligand-independent manner ( $\mathrm{Hu}$ et al. 2009, Dehm \& Tindall 2011, Hornberg et al. 2011, Lu \& Luo 2013, Antonarakis et al. 2014, Djusberg et al. 2017, Jernberg et al. 2017, Prekovic et al. 2018).

(b) Reactivation of the AR transcriptional program via an alternate steroid receptor. Four steroid receptors (AR, progesterone receptor (PR), glucocorticoid receptor (GR) and mineralocorticoid receptor (MR)) can recognize and bind to the same DNA motif, allowing for overlap in their transcriptional output and functional compensation (Isikbay et al. 2014). Active AR suppresses not only its own expression, but also the expression of GR. Consequently, inhibition of the AR axis results in derepressed expression of both AR and GR, and GR activity can bypass the AR blockade from ARSIs (Arora et al. 2013, Xie et al. 2015, Puhr et al. 2018).

(c) AR-program-independent mechanisms of resistance such as: (c) 2021 Society for Endocrinology Published by Bioscientifica Ltd. Printed in Great Britain 
Increased activation of kinase pathways, for example, PI3K/AKT (Carver et al. 2011, Liu \& Dong 2014, Adelaiye-Ogala et al. 2020) and receptor tyrosine kinases (RTKs) (Drake et al. 2012, 2013, 2014, 2016, Faltermeier et al. 2016, VanDeusen et al. 2020).

Cell lineage plasticity and transdifferentiation from a luminal epithelial phenotype to other AR-indifferent phenotypes, including neuroendocrine (NEPC), small cell, as well as the double-negative PC (DNPC) that is both AR-negative and neuroendocrinenegative and is driven by the FGF and MAPK pathways (Bluemn et al. 2017, Abida et al. 2019, Handle et al. 2019, Yamada \& Beltran 2021). An aberrant CRPC type with a gastrointestinal-lineage transcriptome has also been described (Shukla et al. 2017). Such transdifferentiation is frequently driven by transcription factors (ONECUT2, HNF4G, HNF1A, SOX2, ASCL1, BRN2, MYCN), epigenetic changes in DNA methylation, histone modifications, chromatin integrity and accessibility, and EZH2 activity (Beltran et al. 2011, Shukla et al. 2017, Abida et al. 2019, Yamada \& Beltran 2021). Ku et al. reported that EZH2 inhibition is able to reverse the lineage switch and restore the sensitivity to AR-targeted therapy (Ku et al. 2017). Interestingly, several of the transcription factors driving this transdifferentiation are suppressed by AR under hormone-replete conditions; thus deep AR axis inhibition results in their derepressed expression. In other words, the emergence of these NEPC and other AR-indifferent CRPC phenotypes is not via random, stochastic events, but is based on pre-determined transcriptional programs that were repressed by androgen, and thus represent an inescapable consequence of deep AR inhibition (Kaochar \& Mitsiades 2019). In agreement, these AR-indifferent PC phenotypes are very rarely seen de novo in hormonenaïv PC patients, become more frequent in CRPC after SADT, and even more common after the use of ARSIs for deeper AR inhibition. In parallel, the related process of epithelial-mesenchymal transition (EMT) (Dicken et al. 2019), which is involved in cancer cell invasion and metastasis (Kahn et al. 2014), has been shown to be regulated by the androgen-AR signaling axis. Complex and frequently opposing effects of AR signaling on EMT have been reported (Zhu \& Kyprianou 2010, Matuszak \& Kyprianou 2011, Jacob et al. 2014, Nakazawa \& Kyprianou 2017, Lin et al. 2018).

\section{Future directions}

This year marks not only the 80-year anniversary of ADT, but also the 10-year anniversary of the introduction of the first successful ARSI to the market (abiraterone 2011). In the past decade, ARSIs have prolonged survival and improved quality of life for many PC patients, but resistance eventually emerges in the clinic and requires innovative approaches to address it.

In the case of ARSI-resistance driven by full-length AR, there is room for additional inhibition, for example, via degradation by proteolysis targeting chimeras (PROTACs) (Han et al. 2019, Neklesa et al. 2019, Kregel et al. 2020, Petrylak et al. 2020), an approach that can target both ligand-dependent and ligand-independent functions of full-length AR. A PROTAC consists of a protein-ligand domain (that recruits the target protein), a linker region, and a ligase ligand domain (that binds a specific E3 ubiquitin ligase, which will ubiquitinate the protein of interest and promote its degradation). One advantage of PROTACs is their activity at very low concentrations, because they promote the degradation of their target proteins, essentially functioning in a catalytic manner and not as competitive antagonists. The protein-ligand domain is obviously critical in determining which forms of the target protein will be degraded. The presence of a LBD on full-length AR makes it an obvious choice for PROTAC design but also limits PROTAC activity accordingly. For example, ARCC-4, a prototypic PROTAC that was designed by linking enzalutamide to a VHL E3 ligase ligand, promotes the degradation of full-length AR, including of the F877L mutant that is functionally activated by the parent LBD ligand (enzalutamide). Thus, the switch from a competitive antagonism mechanism to a degradation-promoting mechanism of action can broaden the spectrum of activity of a LBD ligand. However, as expected, ARCC-4 cannot promote degradation of the LBD-lacking ARv7 (Salami et al. 2018). Similarly, ARV-110, a related PROTAC that is already in clinical trials, targets for degradation WT full-length AR and many of its variants (T878A, H875Y, F877L, M895V), but not L702H or ARv7 (Neklesa 2019, Petrylak 2020).

As a result, for ARSI-resistant CRPCs driven by AR variants that lack the LBD, a different approach is needed. The N-terminal domain (NTD) of AR (which is present in all AR variants, including LBD-mutants and LBDlacking splice variants), has been proposed as druggable, and clinical results from this promising approach are eagerly awaited (Andersen et al. 2010, Myung et al. 2013, Banuelos et al. 2016, Sadar 2020). 
Our prediction is that further targeting of AR, either at the LBD or at the NTD, may benefit select patients with specific mechanisms of resistance such as ligand-dependent (e.g. LBD-mutant AR) and ligand-independent (e.g. LBDlacking splice variants) CRPC, thus having a clinical value in a biomarker-driven manner. However, at the same time, they would be expected to drive even more CRPCs, as an adaptive pre-determined mechanism, toward AR-indifferent biology and, in particular, treatment-associated NEPC and related phenotypes. This will further increase the urgent need for developing targeted therapies to address this lethal transition (Beltran \& Demichelis 2021).

Another direction is to combine ARSIs with other pathway inhibitors in a biomarker-guided approach. For example, the addition of the Akt inhibitor ipatasertib to the CYP17 inhibitor abiraterone in patients with mCRPC showed superior antitumor activity to abiraterone alone in a phase Ib/II study, especially in patients with PTEN loss (de Bono et al. 2019). In the subsequent phase III, randomized, double-blind IPATential150 study, adding ipatasertib to abiraterone in asymptomatic or mildly symptomatic patients previously untreated for $\mathrm{MCRPC}$, improved PFS in patients who had PTEN loss (de Bono et al. 2020). Other combinations of ARSIs with PARP inhibitors (Rao et al. 2021) or chemotherapy (Smith et al. 2018a) are currently being investigated as well.

However, combination regimens need to be approached carefully and in a manner driven by rationale, mechanism and evidence. Not all combinations benefit patients, as described above regarding combinations involving $\mathrm{AA}+\mathrm{P}$ plus a second generation anti-androgen. Furthermore, in ERA-223, a randomized, double-blind, placebo-controlled, phase 3 trial in chemotherapy-naive CRPC with bone metastases, the addition of radium-223 to $\mathrm{AA}+\mathrm{P}$ did not improve symptomatic skeletal event-free survival, and was associated with an increased frequency of bone fractures compared with placebo. In fact, the study was unblinded prematurely, after more fractures and deaths were noted in the radium-223 group than in the placebo group (Smith et al. 2019). Similarly, the addition of enzalutamide to radium-223 did not improve OS (Ahmed et al. 2021). Consequently, these combinations are not recommended at this point.

\section{General thoughts/reflections on the state of the field}

The last decade has seen dramatic progress in the treatment of advanced PC. The four approved ARSIs have improved outcomes for patients and also have validated older concepts about hormonal treatment, thus cementing our understanding of PC biology. Reflecting on these advances, we would like to give some personal opinions:

(a) Is there still a role/indication for using standard ADT as monotherapy without ARSI (thus targeting testicular androgen production only) in any setting in PC?

Technically, in the case of men with high-risk NOM0 or N1M0 (regional lymphadenopathy) CSPC who initiate treatment with $\mathrm{ADT} \pm$ radiation, there is no FDA approval for adding an ARSI to the ADT. As mentioned above, in our clinical practice $(\mathrm{N} \mathrm{M})$, we frequently extrapolate based on the STAMPEDE data (James et al. 2017, Hoyle et al. 2019) and add AA+P, off-label, to the ADT regimen in such patients. Strictly speaking, though, as of February 2021, AA+P is not FDA-approved even for metastatic CSPC that falls in the low-risk M1 stratification (as defined by LATITUDE (Fizazi et al. 2017)), a clinical state for which enzalutamide and apalutamide are approved. Again, our clinical practice (N $\mathrm{M}$ ) is to consider $\mathrm{AA}+\mathrm{P}$, enzalutamide and apalutamide as equally acceptable options for all metastatic CSPC patients who start ADT, irrespective of risk stratification. Finally, for patients who initiate ADT for biochemical recurrence (non-metastatic or M0 disease) after prior prostatectomy or prostate irradiation, there is again no FDA approval for adding any ARSI.

Our personal opinion is that these subtleties (as well as those detailed in Table 1) most likely represent the way clinical trials for each ARSI were designed and prioritized, and do not suggest any actual differences in clinical activity. We anticipate that future evidence will expand the upfront incorporation of ARSIs across the entire space of ADT use. Hence we propose that if a patient is to initiate ADT, he should be offered the best AR axis suppression possible (which, as of February 2021, is ADT+ any one of the four ARSIs that are on the market), unless comorbidities, life expectancy, adverse effects and patient preference would favor otherwise. We believe that failure to add an ARSI allows residual adrenal and intratumoral androgens to persistently activate the AR axis, which increases the opportunities for PC cells to survive, adapt and evolve into CRPC.

(b) How to deal with outdated (and incorrect) terminology?

The term 'androgen deprivation therapy', as used historically (without ARSI), is a misnomer, because intratumoral androgens actually persist (Montgomery et al. 2008). Similarly, the term 'hormoneindependent' PC was a misnomer at the time before ARSIs.
(C) 2021 Society for Endocrinology Published by Bioscientifica Ltd. Printed in Great Britain 
Nowadays, however, ARSIs are approaching the goal of achieving true 'androgen deprivation therapy' at the cellular level, and the resistant PC cells are frequently truly 'hormone-independent' PC at the cellular level (although not always). For example, NEPC could be called a truly hormone-independent PC. So could the term 'androgen-independent' PC make a clinical comeback, this time to describe post-ARSI CRPC that is driven by ligand-independent mechanisms?

Technically, this time the term may be correct at a cellular level for many ARSI-refractory CRPCs and it could be used accurately in select cases after molecular studies have carefully dissected and confirmed such mechanisms of resistance on an individual level, but it would probably be too confusing to bring it back in the clinic to describe ARSI-refractory CRPC. To avoid confusion, use of a different term such as 'androgenindifferent' or similar term, is preferred.

For the same reason, while the current use of second generation anti-androgens together with frontline ADT in metastatic CSPC is essentially a combined androgen blockade (CAB), that term is (unfortunately) linked to the previously tried use of first generation anti-androgens in that setting, so perhaps it would be best to leave that term in the past as well, to avoid confusion.

(c) Better (deeper, earlier, more comprehensive) AR axis targeting will benefit patients, but will also make 'androgen-indifferent' variants more common in an inevitable, deterministic way that is driven by our own hormonal therapies. Metastatic prostate adenocarcinoma patients will receive endocrine therapies for significant periods of time, but the disease phenotype that will be most lethal in the future will resemble small cell cancer of the lung (and perhaps will be treated borrowing principles and advances from that field).

(d) Despite the widespread use of AR targeting as firstline choice for treating advanced PC, it is remarkable that the decision to start hormonal therapy and the choice of the specific hormonal regimen has essentially never been driven by a genetic/genomic biomarker. At a time in Precision Oncology where targeted therapies are chosen for each patient based on matching to activating mutations in their targets, the use of hormonal therapies in advanced PC remains remarkably not biomarker-driven. Review of any genomic dataset from treatment-naïve PC reveals little (if any) evidence to nominate $\mathrm{AR}$ as a major therapeutic target. In fact, AR overexpression, gene amplification, mutations, expression of splice variants, etc., happen in meaningful frequencies only after the hormonal equilibrium of the PC cell has been perturbed by ADT, when depressed feedback loops and escape mechanisms try to re-equilibrate the cell's intracellular signaling balance. In the clinic, we utilize ADT as first-line therapy irrespective of the patient's baseline serum testosterone levels, AR mutation status, or even whether the tumor expresses AR or not. In fact, we do not even test for AR expression in regular clinical practice, although one could point out that the production of PSA by the tumor is evidence of AR activity (but also greatly affected by tumor burden and thus not a quantitatively accurate measure of AR activity). In other words, the clinical algorithm for making decisions regarding when to start hormonal therapy and which agents to use does not incorporate any assessment of the specific degree of AR dependence or any predictive biomarker of responsiveness of each patient's PC to hormonal therapy.

An explanation for this paradox is that ADT does not treat only PC - it treats the entire prostate epithelial lineage as a whole, and we (the physicians) have accepted that normal prostate function will be sacrificed in the process, just as we (the physicians) consider hot flashes, erectile dysfunction, loss of bone density, etc., as unavoidable consequences of ADT. But all these adverse effects add significant morbidity for our patients, which is also becoming more prolonged as their life expectancy increases due to more active therapy. More emphasis on survivorship for ADTtreated patients is needed, and we need clinical trials that will try to mitigate these adverse events such as via intermittent use of ADT \pm ARSI or more refined patient selection. This may at first sound contrary to the point we made above in (a) ('if you initiate ADT, offer the best AR axis suppression possible by adding an ARSI'), but it is actually not. Standard ADT is an incomplete therapy that practically guarantees emergence of CRPC, while the patients still have to suffer the adverse events of androgen deprivation. As an alternative approach, more comprehensive AR axis targeting with ADT+ARSI for shorter periods of time may allow for more definitive control of the cancer that then can be followed by careful withdrawal of hormonal therapy in select cases and under close monitoring. This is similar to the concept of 'intermittent ADT', which in recent years has been less popular, after Hussain et al. (2013) gave us reasons for concern that intermittent ADT may not be adequate therapy. It is possible, though, that, 
just like the ARSIs validated several other old concepts in the last decade, they could also resurrect the concept of cycling between periods of intense therapy and de-intensification. Again, the theme is to look back at older paradigms that possibly had value but previously failed in the clinic due to lack of appropriate pharmacological agents, and examine them again in well-designed, biomarker-driven clinical trials that incorporate ARSIs.

(e) And finally, we close our article honoring the pioneering work of Huggins \& Hodges (1941) by mentioning the Holy Grail of AR targeting in PC: to separate the growth-promoting effects of AR signaling on PC cells from the normal functions of androgens and AR in the rest of the body, so that we can, someday, selectively target PC cells while sparing healthy cells in the body, thus minimizing the adverse events of ADT for our patients. The work continues!

\section{Declaration of interest}

Salma Kaochar has received honoraria from FGH BioTech and research funding from FGH BioTech and Systems Oncology. Nicholas Mitsiades has no financial or other potential conflicts of interest.

\section{Funding}

This work was also supported by the Prostate Cancer Foundation (to $\mathrm{S} \mathrm{K}$ and $\mathrm{N} \mathrm{M}$ ), the Terry Fox Foundation (to N M), and National Cancer Institute Grant U54-CA233223 (to S K and N M). The authors also would like to acknowledge the assistance of the Dan L. Duncan Cancer Center (supported by the NCl Cancer Center Support Grant P30CA125123).

\section{Acknowledgements}

The authors acknowledge the joint participation by Adrienne Helis Malvin Medical Research Foundation through its direct engagement in the continuous active conduct of medical research in conjunction with Baylor College of Medicine.

\section{References}

Abida W, Cyrta J, Heller G \& Prandi D, Armenia J, Coleman I, Cieslik M, Benelli M, Robinson D, Van Allen EM, et al. 2019 Genomic correlates of clinical outcome in advanced prostate cancer. PNAS 116 11428-11436. (https://doi.org/10.1073/pnas.1902651116)

Abratt RP, Brune D, Dimopoulos MA, Kliment J, Breza J, Selvaggi FP, Beuzeboc P, Demkow T \& Oudard S 2004 Randomised phase III study of intravenous vinorelbine plus hormone therapy versus hormone therapy alone in hormone-refractory prostate cancer. Annals of Oncology 15 1613-1621. (https://doi.org/10.1093/annonc/mdh429)

Adelaiye-Ogala R, Gryder BE, Nguyen YTM, Alilin AN, Grayson AR, Bajwa W, Jansson KH, Beshiri ML, Agarwal S, Rodriguez-Nieves JA, et al. 2020 Targeting the PI3K/AKT pathway overcomes enzalutamide resistance by inhibiting induction of the glucocorticoid receptor. Molecular Cancer Therapeutics 19 1436-1447. (https://doi. org/10.1158/1535-7163.MCT-19-0936)
Agoulnik IU, Vaid A, Bingman 3rd WE, Erdeme H, Frolov A, Smith CL, Ayala G, Ittmann MM \& Weigel NL 2005 Role of SRC-1 in the promotion of prostate cancer cell growth and tumor progression. Cancer Research 65 7959-7967. (https://doi.org/10.1158/0008-5472. CAN-04-3541)

Agoulnik IU, Vaid A, Nakka M, Alvarado M, Bingman 3rd WE, Erdem H, Frolov A, Smith CL, Ayala GE, Ittmann MM, et al. 2006 Androgens modulate expression of transcription intermediary factor 2 , an androgen receptor coactivator whose expression level correlates with early biochemical recurrence in prostate cancer. Cancer Research $\mathbf{6 6}$ 10594-10602. (https://doi.org/10.1158/0008-5472.CAN-06-1023)

Ahmed ME, Joshi VB, Badawy M, Pagliaro LC, Karnes RJ, Lowe V, Thorpe MP Kwon ED \& Kendi AT 2021 Radium-223 in the third-line setting in metastatic castrate-resistant prostate cancer (mCRPC): impact of concomitant use of enzalutamide on overall survival and predictors of improved overall survival. Clinical Genitourinary Cancer [epub]. (https://doi.org/10.1016/j.clgc.2020.12.009)

Andersen RJ, Mawji NR, Wang J, Wang G, Haile S, Myung JK, Watt K, Tam T, Yang YC, Banuelos CA, et al. 2010 Regression of castraterecurrent prostate cancer by a small-molecule inhibitor of the aminoterminus domain of the androgen receptor. Cancer Cell 17 535-546. (https://doi.org/10.1016/j.ccr.2010.04.027)

Antonarakis ES, Lu C, Wang H, Luber B, Nakazawa M, Roeser JC, Chen Y, Mohammad TA, Chen Y, Fedor HL, et al. 2014 AR-V7 and resistance to enzalutamide and abiraterone in prostate cancer. New England Journal of Medicine 371 1028-1038. (https://doi.org/10.1056/NEJMoa1315815) Armstrong AJ, Szmulewitz RZ, Petrylak DP, Holzbeierlein J, Villers A, Azad A, Alcaraz A, Alekseev B, Iguchi T, Shore ND, et al. 2019 ARCHES: a randomized, phase III study of androgen deprivation therapy with enzalutamide or placebo in men with metastatic hormone-sensitive prostate cancer. Journal of Clinical Oncology 37 2974-2986.

Arora VK, Schenkein E, Murali R, Subudhi SK, Wongvipat J, Balbas MD, Shah N, Cai L, Efstathiou E, Logothetis C, et al. 2013 Glucocorticoid receptor confers resistance to antiandrogens by bypassing androgen receptor blockade. Cell 155 1309-1322. (https://doi.org/10.1016/j. cell.2013.11.012)

Attard G, Sydes MR, Mason MD, Clarke NW, Aebersold D, de Bono JS, Dearnaley DP, Parker CC, Ritchie AW, Russell JM, et al. 2014 Combining enzalutamide with abiraterone, prednisone, and androgen deprivation therapy in the STAMPEDE trial. European Urology 66 799-802. (https://doi.org/10.1016/j.eururo.2014.05.038)

Attard G, Borre M, Gurney H, Loriot Y, Andresen-Daniil C, Kalleda R, Pham T, Taplin ME \& PLATO Collaborators 2018 Abiraterone alone or in combination with enzalutamide in metastatic castration-resistant prostate cancer with rising prostate-specific antigen during enzalutamide treatment. Journal of Clinical Oncology 36 2639-2646. (https://doi.org/10.1200/JCO.2018.77.9827)

Azad AA, Eigl BJ, Murray RN, Kollmannsberger C \& Chi KN 2015a Efficacy of enzalutamide following abiraterone acetate in chemotherapy-naive metastatic castration-resistant prostate cancer patients. European Urology 67 23-29. (https://doi.org/10.1016/j.eururo.2014.06.045)

Azad AA, Volik SV, Wyatt AW, Haegert A, Le Bihan S, Bell RH, Anderson SA, McConeghy B, Shukin R, Bazov J, et al. 2015b Androgen receptor gene aberrations in circulating cell-free DNA: biomarkers of therapeutic resistance in castration-resistant prostate cancer. Clinical Cancer Research 21 2315-2324. (https://doi.org/10.1158/1078-0432.CCR-14-2666)

Balbas MD, Evans MJ, Hosfield DJ, Wongvipat J, Arora VK, Watson PA, Chen Y, Greene GL, Shen Y \& Sawyers CL 2013 Overcoming mutationbased resistance to antiandrogens with rational drug design. eLife $\mathbf{2}$ e00499. (https://doi.org/10.7554/eLife.00499)

Balk SP 2002 Androgen receptor as a target in androgen-independent prostate cancer. Urology 60 (Supplement 1) 132-138. (https://doi. org/10.1016/s0090-4295(02)01593-5)

Banuelos CA, Tavakoli I, Tien AH, Caley DP, Mawji NR, Li Z, Wang J, Yang YC, Imamura Y, Yan L, et al. 2016 Sintokamide A is a novel antagonist of androgen receptor that uniquely binds activation function-1 in its amino-terminal domain. Journal of Biological 
Chemistry 291 22231-22243. (https://doi.org/10.1074/jbc. M116.734475)

Bedoya DJ \& Mitsiades N 2013 Clinical appraisal of abiraterone in the treatment of metastatic prostatic cancer: patient considerations, novel opportunities, and future directions. OncoTargets and Therapy 6 9-18. (https://doi.org/10.2147/OTT.S24941)

Beer TM, Armstrong AJ, Rathkopf DE, Loriot Y, Sternberg CN, Higano CS, Iversen P, Bhattacharya S, Carles J, Chowdhury S, et al. 2014 Enzalutamide in metastatic prostate cancer before chemotherapy. New England Journal of Medicine 371 424-433.

Beltran H, Rickman DS, Park K, Chae SS, Sboner A, MacDonald TY, Wang Y, Sheikh KL, Terry S, Tagawa ST, et al. 2011 Molecular characterization of neuroendocrine prostate cancer and identification of new drug targets. Cancer Discovery 1 487-495. (https://doi. org/10.1158/2159-8290.CD-11-0130)

Beltran H \& Demichelis F 2021 Therapy considerations in neuroendocrine prostate cancer: what next? Endocrine-Related Cancer 28 67-78. (https:// doi.org/10.1530/ERC-21-0140)

Berry W, Dakhil S, Modiano M, Gregurich M \& Asmar L 2002 Phase III study of mitoxantrone plus low dose prednisone versus low dose prednisone alone in patients with asymptomatic hormone refractory prostate cancer. Journal of Urology 168 2439-2443. (https://doi. org/10.1097/01.ju.0000035648.32750.00)

Bertaglia V, Tucci M, Fiori C, Aroasio E, Poggio M, Buttigliero C, Grande S, Saini A, Porpiglia F \& Berruti A 2013 Effects of serum testosterone levels after 6 months of androgen deprivation therapy on the outcome of patients with prostate cancer. Clinical Genitourinary Cancer 11 325.e1-330.e1. (https://doi.org/10.1016/j. clgc.2013.01.002)

Bianchini D, Lorente D, Rodriguez-Vida A, Omlin A, Pezaro C, Ferraldeschi R, Zivi A, Attard G, Chowdhury S \& de Bono JS 2014 Antitumour activity of enzalutamide (MDV3100) in patients with metastatic castration-resistant prostate cancer (CRPC) pre-treated with docetaxel and abiraterone. European Journal of Cancer 50 78-84. (https://doi.org/10.1016/j.ejca.2013.08.020)

Bluemn EG, Coleman IM, Lucas JM, Coleman RT, Hernandez-Lopez S, Tharakan R, Bianchi-Frias D, Dumpit RF, Kaipainen A, Corella AN, et al. 2017 Androgen receptor pathway-independent prostate cancer is sustained through FGF signaling. Cancer Cell 32 474.e6-489.e6. (https://doi.org/10.1016/j.ccell.2017.09.003)

Cai C, Chen S, Ng P, Bubley GJ, Nelson PS, Mostaghel EA, Marck B, Matsumoto AM, Simon NI, Wang H, et al. 2011 Intratumoral de novo steroid synthesis activates androgen receptor in castration-resistant prostate cancer and is upregulated by treatment with CYP17A1 inhibitors. Cancer Research 71 6503-6513. (https://doi. org/10.1158/0008-5472.CAN-11-0532)

Carver BS, Chapinski C, Wongvipat J, Hieronymus H, Chen Y, Chandarlapaty S, Arora VK, Le C, Koutcher J, Scher H, et al. 2011 Reciprocal feedback regulation of PI3K and androgen receptor signaling in PTEN-deficient prostate cancer. Cancer Cell 19 575-586. (https://doi.org/10.1016/j.ccr.2011.04.008)

Chen CD, Welsbie DS, Tran C, Baek SH, Chen R, Vessella R, Rosenfeld MG \& Sawyers CL 2004 Molecular determinants of resistance to antiandrogen therapy. Nature Medicine 10 33-39. (https://doi. org/10.1038/nm972)

Chen Y, Clegg NJ \& Scher HI 2009 Anti-androgens and androgendepleting therapies in prostate cancer: new agents for an established target. Lancet: Oncology 10 981-991. (https://doi.org/10.1016/S14702045(09)70229-3)

Chen EJ, Sowalsky AG, Gao S, Cai C, Voznesensky O, Schaefer R, Loda M, True LD, Ye H, Troncoso P, et al. 2015a Abiraterone treatment in castration-resistant prostate cancer selects for progesterone responsive mutant androgen receptors. Clinical Cancer Research 21 1273-1280. (https://doi.org/10.1158/1078-0432.CCR-14-1220)

Chen Z, Lan X, Thomas-Ahner JM, Wu D, Liu X, Ye Z, Wang L, Sunkel B, Grenade C, Chen J, et al. 2015b Agonist and antagonist switch DNA motifs recognized by human androgen receptor in prostate cancer. EMBO Journal 34 502-516. (https://doi.org/10.15252/embj.201490306)

Chi KN, Agarwal N, Bjartell A, Chung BH, Pereira de Santana Gomes AJ, Given R, Juarez Soto A, Merseburger AS, Ozguroglu M, Uemura H, et al. 2019 Apalutamide for metastatic, castration-sensitive prostate cancer. New England Journal of Medicine 381 13-24.

Chi KN, Chowdhury S, Bjartell A, Chung BH, Pereira de Santana Gomes AJ, Given R, Juárez Soto Á, Merseburger AS, Ozguroglu M, Uemura H, et al. 2021 Final analysis results from TITAN: A phase III study of apalutamide (APA) versus placebo ( $\mathrm{PBO}$ ) in patients (pts) with metastatic castration-sensitive prostate cancer (mCSPC) receiving androgen deprivation therapy (ADT). Journal of Clinical Oncology 3911.

Clegg NJ, Wongvipat J, Joseph JD, Tran C, Ouk S, Dilhas A, Chen Y, Grillot K, Bischoff ED, Cai L, et al. 2012 ARN-509: a novel antiandrogen for prostate cancer treatment. Cancer Research $\mathbf{7 2}$ 1494-1503. (https://doi.org/10.1158/0008-5472.CAN-11-3948)

Coarfa C, Fiskus W, Eedunuri VK, Rajapakshe K, Foley C, Chew SA, Shah SS, Geng C, Shou J, Mohamed JS, et al. 2016 Comprehensive proteomic profiling identifies the androgen receptor axis and other signaling pathways as targets of microRNAs suppressed in metastatic prostate cancer. Oncogene 35 2345-2356. (https://doi.org/10.1038/onc.2015.295)

Culig Z, Hoffmann J, Erdel M, Eder IE, Hobisch A, Hittmair A, Bartsch G, Utermann G, Schneider MR, Parczyk K, et al. 1999 Switch from antagonist to agonist of the androgen receptor bicalutamide is associated with prostate tumour progression in a new model system. British Journal of Cancer 81 242-251. (https://doi.org/10.1038/sj. bjc.6690684)

Danila DC, Morris MJ, de Bono JS, Ryan CJ, Denmeade SR, Smith MR, Taplin ME, Bubley GJ, Kheoh T, Haqq C, et al. 2010 Phase II multicenter study of abiraterone acetate plus prednisone therapy in patients with docetaxel-treated castration-resistant prostate cancer. Journal of Clinical Oncology 28 1496-1501. (https://doi.org/10.1200/ JCO.2009.25.9259)

Davis ID, Martin AJ, Stockler MR, Begbie S, Chi KN, Chowdhury S, Coskinas X, Frydenberg M, Hague WE, Horvath LG, et al. 2019 Enzalutamide with standard first-line therapy in metastatic prostate cancer. New England Journal of Medicine 381 121-131.

de Bono JS, Logothetis CJ, Molina A, Fizazi K, North S, Chu L, Chi KN, Jones RJ, Goodman OB Jr, Saad F, et al. 2011 Abiraterone and increased survival in metastatic prostate cancer. New England Journal of Medicine 364 1995-2005.

de Bono JS, Chowdhury S, Feyerabend S, Elliott T, Grande E, MelhemBertrandt A, Baron B, Hirmand M, Werbrouck P \& Fizazi K 2018 Antitumour activity and safety of enzalutamide in patients with metastatic castration-resistant prostate cancer previously treated with abiraterone acetate plus prednisone for $\geq 24$ weeks in Europe. European Urology 74 37-45. (https://doi.org/10.1016/j.eururo.2017.07.035)

de Bono JS, De Giorgi U, Rodrigues DN, Massard C, Bracarda S, Font A, Arranz Arija JA, Shih KC, Radavoi GD, Xu N, et al. 2019 Randomized Phase II study evaluating Akt blockade with ipatasertib, in combination with abiraterone, in patients with metastatic prostate cancer with and without PTEN loss. Clinical Cancer Research $\mathbf{2 5}$ 928-936. (https://doi.org/10.1158/1078-0432.CCR-18-0981)

de Bono JS, Bracarda S, Sternberg CN, Chi KN, Olmos D, Sandhu S, Massard C, Matsubara N, Alekseev B, Gafanov R, et al. 2020 LBA4 IPATential150: Phase III study of ipatasertib (ipat) plus abiraterone (abi) vs placebo (pbo) plus abi in metastatic castration-resistant prostate cancer (mCRPC). Annals of Oncology 31 S1153-S1154. (https:// doi.org/10.1016/j.annonc.2020.08.2250)

de Wit R, de Bono J, Sternberg CN, Fizazi K, Tombal B, Wulfing C, Kramer G, Eymard JC, Bamias A, Carles J, et al. 2019 Cabazitaxel versus abiraterone or enzalutamide in metastatic prostate cancer. New England Journal of Medicine 381 2506-2518. (https://doi.org/10.1056/NEJMoa1911206)

Dehm SM \& Tindall DJ 2011 Alternatively spliced androgen receptor variants. Endocrine-Related Cancer 18 R183-R196. (https://doi. org/10.1530/ERC-11-0141) https://erc.bioscientifica.com

https://doi.org/10.1530/ERC-21-0098 (c) 2021 Society for Endocrinology Published by Bioscientifica Ltd. Printed in Great Britain 
Dicken H, Hensley PJ \& Kyprianou N 2019 Prostate tumor neuroendocrine differentiation via EMT: the road less traveled. Asian Journal of Urology 6 82-90. (https://doi.org/10.1016/j.ajur.2018.11.001)

Djusberg E, Jernberg E, Thysell E, Golovleva I, Lundberg P, Crnalic S, Widmark A, Bergh A, Brattsand M \& Wikstrom P 2017 High levels of the AR-V7 splice variant and co-amplification of the golgi protein coding YIPF6 in AR amplified prostate cancer bone metastases. Prostate 77 625-638. (https://doi.org/10.1002/pros.23307)

Drake JM, Graham NA, Stoyanova T, Sedghi A, Goldstein AS, Cai H, Smith DA, Zhang H, Komisopoulou E, Huang J, et al. 2012 Oncogenespecific activation of tyrosine kinase networks during prostate cancer progression. PNAS 109 1643-1648. (https://doi.org/10.1073/ pnas.1120985109)

Drake JM, Graham NA, Lee JK, Stoyanova T, Faltermeier CM, Sud S, Titz B, Huang J, Pienta KJ, Graeber TG, et al. 2013 Metastatic castrationresistant prostate cancer reveals intrapatient similarity and interpatient heterogeneity of therapeutic kinase targets. PNAS $\mathbf{1 1 0}$ E4762-E4769. (https://doi.org/10.1073/pnas.1319948110)

Drake JM, Lee JK \& Witte ON 2014 Clinical targeting of mutated and wildtype protein tyrosine kinases in cancer. Molecular and Cellular Biology 34 1722-1732. (https://doi.org/10.1128/MCB.01592-13)

Drake JM, Paull EO, Graham NA, Lee JK, Smith BA, Titz B, Stoyanova T, Faltermeier CM, Uzunangelov V, Carlin DE, et al. 2016 Phosphoproteome integration reveals patient-specific networks in prostate cancer. Cell 166 1041-1054. (https://doi.org/10.1016/j.cell.2016.07.007)

Efstathiou E, Boukovala MA, Spetsieris N, Wen S, Hoang A, Weldon JA, Tidwell R, Davis JW, Chapin BF, Corn PG, et al. 2020 Neoadjuvant apalutamide (APA) plus leuprolide (LHRHa) with or without abiraterone (AA) in localized high-risk prostate cancer (LHRPC). Journal of Clinical Oncology 38 5504-5504. (https://doi.org/10.1200/ JCO.2020.38.15_suppl.5504)

Faltermeier CM, Drake JM, Clark PM, Smith BA, Zong Y, Volpe C, Mathis C, Morrissey C, Castor B, Huang J, et al. 2016 Functional screen identifies kinases driving prostate cancer visceral and bone metastasis. PNAS 113 E172-E181. (https://doi.org/10.1073/pnas.1521674112)

Fizazi K, Tran N, Fein L, Matsubara N, Rodriguez-Antolin A, Alekseev BY, Ozguroglu M, Ye D, Feyerabend S, Protheroe A, et al. 2017 Abiraterone plus prednisone in metastatic, castration-sensitive prostate cancer. New England Journal of Medicine 377 352-360. (https://doi.org/10.1056/ NEJMoa1704174)

Fizazi K, Shore N, Tammela TL, Ulys A, Vjaters E, Polyakov S, Jievaltas M, Luz M, Alekseev B, Kuss I, et al. 2019 Darolutamide in nonmetastatic, castration-resistant prostate cancer. New England Journal of Medicine 380 1235-1246. (https://doi.org/10.1056/NEJMoa1815671)

Fizazi K, Shore N, Tammela TL, Ulys A, Vjaters E, Polyakov S, Jievaltas M, Luz M, Alekseev B, Kuss I, et al. 2020 Nonmetastatic, castration-resistant prostate cancer and survival with darolutamide. New England Journal of Medicine 383 1040-1049. (https://doi.org/10.1056/NEJMoa2001342)

Flaig TW, Plets M, Hussain MHA, Agarwal N, Mitsiades N, Deshpande HA, Vaishampayan UN \& Thompson Jr IM 2017 Abiraterone acetate for metastatic prostate cancer in patients with suboptimal biochemical response to hormone induction. JAMA Oncology 3 e170231. (https:// doi.org/10.1001/jamaoncol.2017.0231)

Foley C \& Mitsiades N 2016 Moving Beyond the androgen receptor (AR): targeting AR-interacting proteinS to treat prostate cancer. Hormones and Cancer 7 84-103. (https://doi.org/10.1007/s12672-015-0239-9)

Fossa SD, Slee PH, Brausi M, Horenblas S, Hall RR, Hetherington JW, Aaronson N, de Prijck L \& Collette L 2001 Flutamide versus prednisone in patients with prostate cancer symptomatically progressing after androgen-ablative therapy: a phase III study of the European Organization for Research and Treatment of Cancer Genitourinary Group. Journal of Clinical Oncology 19 62-71. (https:// doi.org/10.1200/JCO.2001.19.1.62)

Gottlieb B, Beitel LK, Nadarajah A, Paliouras M \& Trifiro M 2012 The androgen receptor gene mutations database: 2012 update. Human Mutation 33 887-894. (https://doi.org/10.1002/humu.22046)
Grasso CS, Wu YM, Robinson DR, Cao X, Dhanasekaran SM, Khan AP, Quist MJ, Jing X, Lonigro RJ, Brenner JC, et al. 2012 The mutational landscape of lethal castration-resistant prostate cancer. Nature $\mathbf{4 8 7}$ 239-243. (https://doi.org/10.1038/nature11125)

Gregory CW, He B, Johnson RT, Ford OH, Mohler JL, French FS \& Wilson EM 2001 A mechanism for androgen receptor-mediated prostate cancer recurrence after androgen deprivation therapy. Cancer Research 61 4315-4319.

Haidar S, Ehmer PB, Barassin S, Batzl-Hartmann C \& Hartmann RW 2003 Effects of novel 17alpha-hydroxylase/C17, 20-lyase (P450 17, CYP 17) inhibitors on androgen biosynthesis in vitro and in vivo. Journal of Steroid Biochemistry and Molecular Biology 84 555-562. (https://doi. org/10.1016/s0960-0760(03)00070-0)

Han X, Wang C, Qin C, Xiang W, Fernandez-Salas E, Yang CY, Wang M, Zhao L, Xu T, Chinnaswamy K, et al. 2019 Discovery of ARD-69 as a highly potent proteolysis targeting chimera (Protac) degrader of androgen receptor (AR) for the treatment of prostate cancer. Journal of Medicinal Chemistry 62 941-964. (https://doi.org/10.1021/acs. jmedchem.8b01631)

Handle F, Prekovic S, Helsen C, Van den Broeck T, Smeets E, Moris L, Eerlings R, Kharraz SE, Urbanucci A, Mills IG, et al. 2019 Drivers of AR indifferent anti-androgen resistance in prostate cancer cells. Scientific Reports 9 13786. (https://doi.org/10.1038/s41598-019-50220-1)

Hara T, Miyazaki J, Araki H, Yamaoka M, Kanzaki N, Kusaka M \& Miyamoto M 2003 Novel mutations of androgen receptor: a possible mechanism of bicalutamide withdrawal syndrome. Cancer Research 63 149-153.

He B, Lanz RB, Fiskus W, Geng C, Yi P, Hartig SM, Rajapakshe K, Shou J, Wei L, Shah SS, et al. 2014 GATA2 facilitates steroid receptor coactivator recruitment to the androgen receptor complex. PNAS 111 18261-18266. (https://doi.org/10.1073/pnas.1421415111)

Hornberg E, Ylitalo EB, Crnalic S, Antti H, Stattin P, Widmark A, Bergh A \& Wikstrom P 2011 Expression of androgen receptor splice variants in prostate cancer bone metastases is associated with castrationresistance and short survival. PLoS ONE 6 e19059. (https://doi. org/10.1371/journal.pone.0019059)

Hoyle AP, Ali A, James ND, Cook A, Parker CC, de Bono JS, Attard G, Chowdhury S, Cross WR, Dearnaley DP, et al. 2019 Abiraterone in 'high-' and 'low-risk' metastatic hormone-sensitive prostate cancer. European Urology 76 719-728. (https://doi.org/10.1016/j. eururo.2019.08.006)

Hu R, Dunn TA, Wei S, Isharwal S, Veltri RW, Humphreys E, Han M, Partin AW, Vessella RL, Isaacs WB, et al. 2009 Ligand-independent androgen receptor variants derived from splicing of cryptic exons signify hormone-refractory prostate cancer. Cancer Research 69 16-22. (https://doi.org/10.1158/0008-5472.CAN-08-2764)

Huggins C \& Hodges CV 1941 Studies on prostatic cancer. I. The effect of castration, of estrogen and of androgen injection on serum phosphatases in metastatic carcinoma of the prostate. Cancer Research 1 293-297.

Hussain M, Tangen CM, Higano C, Schelhammer PF, Faulkner J, Crawford ED, Wilding G, Akdas A, Small EJ, Donnelly B, et al. 2006 Absolute prostate-specific antigen value after androgen deprivation is a strong independent predictor of survival in new metastatic prostate cancer: data from Southwest Oncology Group Trial 9346 (INT-0162). Journal of Clinical Oncology 24 3984-3990. (https://doi.org/10.1200/ JCO.2006.06.4246)

Hussain M, Tangen CM, Berry DL, Higano CS, Crawford ED, Liu G, Wilding G, Prescott S, Kanaga Sundaram S, Small EJ, et al. 2013 Intermittent versus continuous androgen deprivation in prostate cancer. New England Journal of Medicine 368 1314-1325. (https://doi. org/10.1056/NEJMoa1212299)

Hussain M, Fizazi K, Saad F, Rathenborg P, Shore N, Ferreira U, Ivashchenko P, Demirhan E, Modelska K, Phung, et al. 2018 Enzalutamide in men with nonmetastatic, castration-resistant prostate cancer. New England Journal of Medicine 378 2465-2474.
C) 2021 Society for Endocrinology Published by Bioscientifica Ltd. Printed in Great Britain 
Isikbay M, Otto K, Kregel S, Kach J, Cai Y, Vander Griend DJ, Conzen SD \& Szmulewitz RZ 2014 Glucocorticoid receptor activity contributes to resistance to androgen-targeted therapy in prostate cancer. Hormones and Cancer 5 72-89. (https://doi.org/10.1007/s12672-014-0173-2)

Jacob S, Nayak S, Fernandes G, Barai RS, Menon S, Chaudhari UK, Kholkute SD \& Sachdeva G 2014 Androgen receptor as a regulator of ZEB2 expression and its implications in epithelial-to-mesenchymal transition in prostate cancer. Endocrine-Related Cancer 21 473-486. (https://doi.org/10.1530/ERC-13-0514)

James ND, de Bono JS, Spears MR, Clarke NW, Mason MD, Dearnaley DP, Ritchie AWS, Amos CL, Gilson C, Jones RJ, et al. 2017 Abiraterone for prostate cancer not previously treated with hormone therapy. New England Journal of Medicine 377 338-351. (https://doi.org/10.1056/ NEJMoa1702900)

Jernberg E, Bergh A \& Wikstrom P 2017 Clinical relevance of androgen receptor alterations in prostate cancer. Endocrine Connections 6 R146-R161. (https://doi.org/10.1530/EC-17-0118)

Joseph JD, Lu N, Qian J, Sensintaffar J, Shao G, Brigham D, Moon M, Maneval EC, Chen I, Darimont B, et al. 2013 A clinically relevant androgen receptor mutation confers resistance to second-generation antiandrogens enzalutamide and ARN-509. Cancer Discovery 3 1020-1029. (https://doi.org/10.1158/2159-8290.CD-13-0226)

Kahn B, Collazo J \& Kyprianou N 2014 Androgen receptor as a driver of therapeutic resistance in advanced prostate cancer. International Journal of Biological Sciences 10 588-595. (https://doi.org/10.7150/ ijbs.8671)

Kantoff PW, Halabi S, Conaway M, Picus J, Kirshner J, Hars V, Trump D, Winer EP \& Vogelzang NJ 1999 Hydrocortisone with or without mitoxantrone in men with hormone-refractory prostate cancer: results of the cancer and leukemia group B 9182 study. Journal of Clinical Oncology 17 2506-2513. (https://doi.org/10.1200/JCO.1999.17.8.2506)

Kaochar S \& Mitsiades N 2019 Multimodal action of ONECUT2 in driving neuroendocrine prostate cancer. Translational Cancer Research 8 S198-S203. (https://doi.org/10.21037/tcr.2019.02.08)

Kelly WK \& Scher HI 1993 Prostate specific antigen decline after antiandrogen withdrawal: the flutamide withdrawal syndrome. Journal of Urology 149 607-609. (https://doi.org/10.1016/s0022-5347(17)36163-3)

Khalaf DJ, Annala M, Taavitsainen S, Finch DL, Oja C, Vergidis J, Zulfiqar M, Sunderland K, Azad AA, Kollmannsberger CK, et al. 2019 Optimal sequencing of enzalutamide and abiraterone acetate plus prednisone in metastatic castration-resistant prostate cancer: a multicentre, randomised, open-label, phase 2, crossover trial. Lancet: Oncology 20 1730-1739. (https://doi.org/10.1016/S14702045(19)30688-6)

Kim W, Zhang L, Wilton JH, Fetterly G, Mohler JL, Weinberg V, Morse A, Szmulewitz RZ, Friedlander TW, Fong L, et al. 2014 Sequential use of the androgen synthesis inhibitors ketoconazole and abiraterone acetate in castration-resistant prostate cancer and the predictive value of circulating androgens. Clinical Cancer Research 20 6269-6276. (https://doi.org/10.1158/1078-0432.CCR-14-1595)

Klotz L 2008 Maximal androgen blockade for advanced prostate cancer. Best Practice and Research: Clinical Endocrinology and Metabolism 22 331-340. (https://doi.org/10.1016/j.beem.2008.01.004)

Korpal M, Korn JM, Gao X, Rakiec DP, Ruddy DA, Doshi S, Yuan J, Kovats SG, Kim S, Cooke VG, et al. 2013 An F876L mutation in androgen receptor confers genetic and phenotypic resistance to MDV3100 (enzalutamide). Cancer Discovery 3 1030-1043. (https://doi. org/10.1158/2159-8290.CD-13-0142)

Koutsilieris M, Mitsiades C, Dimopoulos T, Ioannidis A, Ntounis A \& Lambou T 2001 A combination therapy of dexamethasone and somatostatin analog reintroduces objective clinical responses to LHRH analog in androgen ablation-refractory prostate cancer patients. Journal of Clinical Endocrinology and Metabolism 86 5729-5736. (https:// doi.org/10.1210/jcem.86.12.8119)

Kregel S, Wang C, Han X, Xiao L, Fernandez-Salas E, Bawa P, McCollum BL, Wilder-Romans K, Apel IJ, Cao X, et al. 2020 Androgen receptor degraders overcome common resistance mechanisms developed during prostate cancer treatment. Neoplasia 22 111-119. (https://doi.org/10.1016/j.neo.2019.12.003)

Kruit WH, Stoter G \& Klijn JG 2004 Effect of combination therapy with aminoglutethimide and hydrocortisone on prostate-specific antigen response in metastatic prostate cancer refractory to standard endocrine therapy. Anti-Cancer Drugs 15 843-847. (https://doi. org/10.1097/00001813-200410000-00004)

Ku SY, Rosario S, Wang Y, Mu P, Seshadri M, Goodrich ZW, Goodrich MM, Labbe DP, Gomez EC, Wang J, et al. 2017 Rb1 and Trp53 cooperate to suppress prostate cancer lineage plasticity, metastasis, and antiandrogen resistance. Science 355 78-83. (https://doi.org/10.1126/ science.aah4199)

Labrie F, Dupont A \& Belanger A 1985 Complete androgen blockade for the treatment of prostate cancer. Important Advances in Oncology 193-217.

Leone G, Tucci M, Buttigliero C, Zichi C, Pignataro D, Bironzo P, Vignani F, Scagliotti GV \& Di Maio M 2018 Antiandrogen withdrawal syndrome (AAWS) in the treatment of patients with prostate cancer. EndocrineRelated Cancer 25 R1-R9. (https://doi.org/10.1530/ERC-17-0355)

Lin CY, Jan YJ, Kuo LK, Wang BJ, Huo C, Jiang SS, Chen SC, Kuo YY, Chang CR \& Chuu CP 2018 Elevation of androgen receptor promotes prostate cancer metastasis by induction of epithelial-mesenchymal transition and reduction of KAT5. Cancer Science 109 3564-3574. (https://doi.org/10.1111/cas.13776)

Liu L \& Dong X 2014 Complex impacts of PI3K/AKT inhibitors to androgen receptor gene expression in prostate cancer cells. PLoS ONE 9 e108780. (https://doi.org/10.1371/journal.pone.0108780)

Loriot Y, Bianchini D, Ileana E, Sandhu S, Patrikidou A, Pezaro C, Albiges L, Attard G, Fizazi K, De Bono JS, et al. 2013 Antitumour activity of abiraterone acetate against metastatic castration-resistant prostate cancer progressing after docetaxel and enzalutamide (MDV3100). Annals of Oncology 24 1807-1812. (https://doi. org/10.1093/annonc/mdt136)

Lu C \& Luo J 2013 Decoding the androgen receptor splice variants. Translational Andrology and Urology 2 178-186. (https://doi. org/10.3978/j.issn.2223-4683.2013.09.08)

Marcelli M, Ittmann M, Mariani S, Sutherland R, Nigam R, Murthy L, Zhao Y, DiConcini D, Puxeddu E, Esen A, et al. 2000 Androgen receptor mutations in prostate cancer. Cancer Research 60 944-949.

Matuszak EA \& Kyprianou N 2011 Androgen regulation of epithelialmesenchymal transition in prostate tumorigenesis. Expert Review of Endocrinology and Metabolism 6 469-482. (https://doi.org/10.1586/ eem.11.32)

McEwan IJ \& Brinkmann AO 2016 Androgen physiology: receptor and metabolic disorders. In Endotext [Internet]. Eds KR Feingold, B Anawalt, A Boyce, G Chrousos, WW de Herder, K Dhatariya, K Dungan, A Grossman, JM Hershman, J Hofland, et al. South Dartmouth (MA): MDText.com, Inc. (available at:https://www.ncbi.nlm.nih.gov/books/ NBK279028/)

McKay RR, Ye H, Xie W, Lis R, Calagua C, Zhang Z, Trinh QD, Chang SL, Harshman LC, Ross AE, et al. 2019 Evaluation of intense androgen deprivation before prostatectomy: a randomized phase II trial of enzalutamide and leuprolide with or without abiraterone. Journal of Clinical Oncology 37 923-931. (https://doi.org/10.1200/JCO.18.01777)

Mitsiades N 2013 A road map to comprehensive androgen receptor axis targeting for castration-resistant prostate cancer. Cancer Research $\mathbf{7 3}$ 4599-4605. (https://doi.org/10.1158/0008-5472.CAN-12-4414)

Mitsiades N, Chen Y \& Scher HI 2011 The AR axis as a pathogenetic mechanism and therapeutic target throughout the clinical states of prostate cancer: opportunities for second-line hormonal manipulations in castration-resistant prostate cancer. In Comprehensive Textbook of Genitourinary Oncology, 4th ed., pp. 262-273. Eds PT Scardino, WM Linehan, MJ Zelefsky, NJ Vogelzang, BI Rini, BH Bochner \& J Sheinfeld. Philadelphia, PA, USA : Lippincott Williams \& Wilkins https://erc.bioscientifica.com

https://doi.org/10.1530/ERC-21-0098 (c) 2021 Society for Endocrinology Published by Bioscientifica Ltd. Printed in Great Britain 
Mitsiades N, Sung CC, Schultz N, Danila DC, He B, Eedunuri VK, Fleisher M, Sander C, Sawyers CL \& Scher HI 2012 Distinct patterns of dysregulated expression of enzymes involved in androgen synthesis and metabolism in metastatic prostate cancer tumors. Cancer Research 72 6142-6152. (https://doi.org/10.1158/0008-5472.CAN-12-1335)

Moilanen AM, Riikonen R, Oksala R, Ravanti L, Aho E, Wohlfahrt G, Nykanen PS, Tormakangas OP, Palvimo JJ \& Kallio PJ 2015 Discovery of ODM-201, a new-generation androgen receptor inhibitor targeting resistance mechanisms to androgen signaling-directed prostate cancer therapies. Scientific Reports 5 12007. (https://doi.org/10.1038/ srep12007)

Montgomery RB, Mostaghel EA, Vessella R, Hess DL, Kalhorn TF, Higano CS, True LD \& Nelson PS 2008 Maintenance of intratumoral androgens in metastatic prostate cancer: a mechanism for castrationresistant tumor growth. Cancer Research 68 4447-4454. (https://doi. org/10.1158/0008-5472.CAN-08-0249)

Mori K, Miura N, Mostafaei H, Quhal F, Sari Motlagh R, Pradere B, Kimura S, Kimura T, Egawa S, Briganti A, et al. 2020 Sequential therapy of abiraterone and enzalutamide in castration-resistant prostate cancer: a systematic review and meta-analysis. Prostate Cancer and Prostatic Diseases 23 539-548. (https://doi.org/10.1038/s41391-0200222-6)

Morioka M, Kobayashi T, Furukawa Y, Jo Y, Shinkai M, Matsuki T, Yamamoto T \& Tanaka H 2002 Prostate-specific antigen levels and prognosis in patients with hormone-refractory prostate cancer treated with low-dose dexamethasone. Urologia Internationalis 68 10-15. (https://doi.org/10.1159/000048411)

Mostaghel EA, Page ST, Lin DW, Fazli L, Coleman IM, True LD, Knudsen B, Hess DL, Nelson CC, Matsumoto AM, et al. 2007 Intraprostatic androgens and androgen-regulated gene expression persist after testosterone suppression: therapeutic implications for castrationresistant prostate cancer. Cancer Research 67 5033-5041. (https://doi. org/10.1158/0008-5472.CAN-06-3332)

Myung JK, Banuelos CA, Fernandez JG, Mawji NR, Wang J, Tien AH, Yang YC, Tavakoli I, Haile S, Watt K, et al. 2013 An androgen receptor $\mathrm{N}$-terminal domain antagonist for treating prostate cancer. Journal of Clinical Investigation 123 2948-2960. (https://doi.org/10.1172/ JCI66398)

Nakazawa M \& Kyprianou N 2017 Epithelial-mesenchymal-transition regulators in prostate cancer: androgens and beyond. Journal of Steroid Biochemistry and Molecular Biology 166 84-90. (https://doi. org/10.1016/j.jsbmb.2016.05.007)

Neklesa T, Snyder LB, Willard RR, Vitale N, Pizzano J, Gordon DA, Bookbinder M, Macaluso J, Dong H, Ferraro C, et al. 2019 ARV-110: an oral androgen receptor PROTAC degrader for prostate cancer. Journal of Clinical Oncology 37259.

Nishimura K, Nonomura N, Yasunaga Y, Takaha N, Inoue H, Sugao H, Yamaguchi S, Ukimura O, Miki T \& Okuyama A 2000 Low doses of oral dexamethasone for hormone-refractory prostate carcinoma. Cancer $\mathbf{8 9}$ 2570-2576. (https://doi.org/10.1002/10970142(20001215)89:12<2570::aid-cncr9>3.0.co;2-h)

Noonan KL, North S, Bitting RL, Armstrong AJ, Ellard SL \& Chi KN 2013 Clinical activity of abiraterone acetate in patients with metastatic castration-resistant prostate cancer progressing after enzalutamide. Annals of Oncology 24 1802-1807. (https://doi.org/10.1093/annonc/mdt138)

Norris JD, Ellison SJ, Baker JG, Stagg DB, Wardell SE, Park S, Alley HM, Baldi RM, Yllanes A, Andreano KJ, et al. 2017 Androgen receptor antagonism drives cytochrome P450 17A1 inhibitor efficacy in prostate cancer. Journal of Clinical Investigation 127 2326-2338. (https://doi.org/10.1172/JCI87328)

Ozyigit G, Hurmuz P, Yuce D \& Akyol F 2019 Prognostic significance of castrate testosterone levels for patients with intermediate and high risk prostate cancer. World Journal of Clinical Oncology 10 283-292. (https:// doi.org/10.5306/wjco.v10.i8.283)

Peer A, Gottfried M, Sinibaldi V, Carducci MA, Eisenberger MA, Sella A, Leibowitz-Amit R, Berger R \& Keizman D 2014 Comparison of abiraterone acetate versus ketoconazole in patients with metastatic castration resistant prostate cancer refractory to docetaxel. Prostate $\mathbf{7 4}$ 433-440. (https://doi.org/10.1002/pros.22765)

Penson DF, Armstrong AJ, Concepcion R, Agarwal N, Olsson C, Karsh L, Dunshee C, Wang F, Wu K, Krivoshik A, et al. 2016 Enzalutamide versus bicalutamide in castration-resistant prostate cancer: the STRIVE trial. Journal of Clinical Oncology 34 2098-2106. (https://doi. org/10.1200/JCO.2015.64.9285)

Perachino M, Cavalli V \& Bravi F 2010 Testosterone levels in patients with metastatic prostate cancer treated with luteinizing hormone-releasing hormone therapy: prognostic significance? BJU International 105 648651. (https://doi.org/10.1111/j.1464-410X.2009.08814.x)

Petrylak DP, Gao X, Vogelzang NJ, Garfield MH, Taylor I, Dougan Moore M, Peck RA \& Burris HA 2020 First-in-human phase I study of ARV-110, an androgen receptor (AR) PROTAC degrader in patients (pts) with metastatic castrate-resistant prostate cancer (mCRPC) following enzalutamide (ENZ) and/or abiraterone (ABI). Journal of Clinical Oncology 383500.

Phillips R 2014 Prostate cancer: an enzalutamide antiandrogen withdrawal syndrome. Nature Reviews: Urology 11 366. (https://doi.org/10.1038/ nrurol.2014.145)

Poole A, Gill D, Hahn AW, Johnson E, Carroll E, Boucher K, Nussenzveig R, Maughan B \& Agarwal N 2017 Incidence and characterization of antiandrogen withdrawal syndrome after discontinuation of treatment with enzalutamide in castration-resistant prostate cancer. Clinical Genitourinary Cancer [epub]. (https://doi.org/10.1016/j. clgc.2017.08.017)

Prekovic S, van den Broeck T, Linder S, van Royen ME, Houtsmuller AB, Handle F, Joniau S, Zwart W \& Claessens F 2018 Molecular underpinnings of enzalutamide resistance. Endocrine-Related Cancer $\mathbf{2 5}$ R545-R557. (https://doi.org/10.1530/ERC-17-0136)

Puhr M, Hoefer J, Eigentler A, Ploner C, Handle F, Schaefer G, Kroon J, Leo A, Heidegger I, Eder I, et al. 2018 The glucocorticoid receptor is a key player for prostate cancer cell survival and a target for improved antiandrogen therapy. Clinical Cancer Research 24 927-938. (https:// doi.org/10.1158/1078-0432.CCR-17-0989)

Quigley DA, Dang HX, Zhao SG, Lloyd P, Aggarwal R, Alumkal JJ, Foye A, Kothari V, Perry MD, Bailey AM, et al. 2018 Genomic hallmarks and structural variation in metastatic prostate cancer. Cell 174 758.e759769.e759.

Rao A, Morris D, Assikis VJ, Jha GG, Ryan CJ, Ablaza A-J, Habeck J, Loehr A, Xiao J \& Gangolli EA 2021 Rucaparib plus enzalutamide in patients (pts) with metastatic castration-resistant prostate cancer (mCRPC): pharmacokinetics (PK) and safety data from the phase Ib RAMP study. Journal of Clinical Oncology 3979.

Rathkopf D \& Scher HI 2013 Androgen receptor antagonists in castrationresistant prostate cancer. Cancer Journal 19 43-49. (https://doi. org/10.1097/PPO.0b013e318282635a)

Rathkopf DE, Efstathiou E, Attard G, Flaig TW, Franke FA, Goodman OB, Oudard S, Steuber T, Suzuki H, Wu D, et al. 2021 Final results from ACIS, a randomized, placebo (PBO)-controlled double-blind phase 3 study of apalutamide (APA) and abiraterone acetate plus prednisone (AAP) versus AAP in patients (pts) with chemo-naive metastatic castration-resistant prostate cancer (mCRPC). Journal of Clinical Oncology 399.

Reid AH, Attard G, Danila DC, Oommen NB, Olmos D, Fong PC, Molife LR, Hunt J, Messiou C, Parker C, et al. 2010 Significant and sustained antitumor activity in post-docetaxel, castration-resistant prostate cancer with the CYP17 inhibitor abiraterone acetate. Journal of Clinical Oncology 28 1489-1495. (https://doi.org/10.1200/ JCO.2009.24.6819)

Relugolix FDA Package Insert 2020 https://www.accessdata.fda.gov/ drugsatfda_docs/label/2020/214621s000lbl.pdf. Accessed on 16 February 2021.

Richards J, Lim AC, Hay CW, Taylor AE, Wingate A, Nowakowska K, Pezaro C, Carreira S, Goodall J, Arlt W, et al. 2012 Interactions of 
abiraterone, eplerenone, and prednisolone with wild-type and mutant androgen receptor: a rationale for increasing abiraterone exposure or combining with MDV3100. Cancer Research 72 2176-2182. (https://doi. org/10.1158/0008-5472.CAN-11-3980)

Rodriguez-Vida A, Bianchini D, Van Hemelrijck M, Hughes S, Malik Z, Powles T, Bahl A, Rudman S, Payne H, de Bono J, et al. 2015 Is there an antiandrogen withdrawal syndrome with enzalutamide? $B J U$ International 115 373-380. (https://doi.org/10.1111/bju.12826)

Romanel A, Gasi Tandefelt D, Conteduca V, Jayaram A, Casiraghi N, Wetterskog D, Salvi S, Amadori D, Zafeiriou Z, Rescigno P, et al. 2015 Plasma AR and abiraterone-resistant prostate cancer. Science Translational Medicine 7 312re10. (https://doi.org/10.1126/scitranslmed. aac9511)

Ryan CJ \& Cheng ML 2013 Abiraterone acetate for the treatment of prostate cancer. Expert Opinion on Pharmacotherapy 14 91-96. (https:// doi.org/10.1517/14656566.2013.745852)

Ryan CJ, Smith MR, de Bono JS, Molina A, Logothetis CJ, de Souza P, Fizazi K, Mainwaring P, Piulats JM, Ng S, et al. 2013 Abiraterone in metastatic prostate cancer without previous chemotherapy. New England Journal of Medicine 368 138-148. (https://doi.org/10.1056/ NEJMoa1209096)

Ryan CJ, Smith MR, Fizazi K, Saad F, Mulders PF, Sternberg CN, Miller K, Logothetis CJ, Shore ND, Small EJ, et al. 2015 Abiraterone acetate plus prednisone versus placebo plus prednisone in chemotherapy-naive men with metastatic castration-resistant prostate cancer (COU-AA-302): final overall survival analysis of a randomised, doubleblind, placebo-controlled phase 3 study. Lancet: Oncology 16 152-160. (https://doi.org/10.1016/S1470-2045(14)71205-7)

Ryan CJ, Crawford ED, Shore ND, Underwood 3rd W, Taplin ME, Londhe A, Francis PSJ, Phillips J, McGowan T \& Kantoff PW 2018 The IMAAGEN study: effect of abiraterone acetate and prednisone on prostate specific antigen and radiographic disease progression in patients with nonmetastatic castration resistant prostate cancer. Journal of Urology 200 344-352. (https://doi.org/10.1016/j. juro.2018.03.125)

Sadar MD 2020 Discovery of drugs that directly target the intrinsically disordered region of the androgen receptor. Expert Opinion on Drug Discovery 15 551-560. (https://doi.org/10.1080/17460441.2020.1732920)

Saika T, Kusaka N, Tsushima T, Yamato T, Ohashi T, Suyama B, Arata R, Nasu Y, Kumon H \& Okayama Urological Cancer Collaborating Group 2001 Treatment of androgen-independent prostate cancer with dexamethasone: a prospective study in stage D2 patients. International Journal of Urology 8 290-294. (https://doi. org/10.1046/j.1442-2042.2001.00302.x)

Salami J, Alabi S, Willard RR, Vitale NJ, Wang J, Dong H, Jin M, McDonnell DP, Crew AP, Neklesa TK, et al. 2018 Androgen receptor degradation by the proteolysis-targeting chimera ARCC-4 outperforms enzalutamide in cellular models of prostate cancer drug resistance. Communications Biology 1 100. (https://doi.org/10.1038/s42003-0180105-8)

Sartor O, Weinberger M, Moore A, Li A \& Figg WD 1998 Effect of prednisone on prostate-specific antigen in patients with hormonerefractory prostate cancer. Urology 52 252-256. (https://doi. org/10.1016/s0090-4295(98)00149-6)

Scher HI, Beer TM, Higano CS, Anand A, Taplin ME, Efstathiou E, Rathkopf D, Shelkey J, Yu EY, Alumkal J, et al. 2010 Antitumour activity of MDV3100 in castration-resistant prostate cancer: a phase 1-2 study. Lancet 375 1437-1446. (https://doi.org/10.1016/S01406736(10)60172-9)

Scher HI, Fizazi K, Saad F, Taplin ME, Sternberg CN, Miller K, de Wit R, Mulders P, Chi KN, Shore ND, et al. 2012 Increased survival with enzalutamide in prostate cancer after chemotherapy. New England Journal of Medicine 367 1187-1197.

Schrader AJ, Schrader MG \& Cronauer MV 2014 Re: Von Klot CA, Kuczyk MA \& Merseburger AS. No androgen withdrawal syndrome for enzalutamide: a report of disease dynamics in the postchemotherapy setting. Eur Urol 2014;65:258-259: Enzalutamide withdrawal syndrome: fact or fiction? European Urology 65 e22-e23.

Shore ND 2017 Darolutamide (ODM-201) for the treatment of prostate cancer. Expert Opinion on Pharmacotherapy 18 945-952. (https://doi.org /10.1080/14656566.2017.1329820)

Shore ND, Chowdhury S, Villers A, Klotz L, Siemens DR, Phung, van Os S, Hasabou N, Wang F, Bhattacharya S, et al. 2016 Efficacy and safety of enzalutamide versus bicalutamide for patients with metastatic prostate cancer (TERRAIN): a randomised, double-blind, phase 2 study. Lancet: Oncology 17 153-163. (https://doi.org/10.1016/S1470-2045(15)00518-5)

Shukla S, Cyrta J, Murphy DA, Walczak EG, Ran L, Agrawal P, Xie Y, Chen Y, Wang S, Zhan Y, et al. 2017 Aberrant activation of a gastrointestinal transcriptional circuit in prostate cancer mediates castration resistance. Cancer Cell 32 792.e7-806.e7. (https://doi. org/10.1016/j.ccell.2017.10.008)

Small EJ, Baron AD, Fippin L \& Apodaca D 1997 Ketoconazole retains activity in advanced prostate cancer patients with progression despite flutamide withdrawal. Journal of Urology 157 1204-1207. (https://doi. org/10.1016/S0022-5347(01)64924-3)

Small EJ, Saad F, Chowdhury S, Oudard S, Hadaschik BA, Graff JN, Olmos D, Mainwaring PN, Lee JY, Uemura H, et al. 2019 Apalutamide and overall survival in non-metastatic castration-resistant prostate cancer. Annals of Oncology 30 1813-1820.

Small EJ, Halabi S, Dawson NA, Stadler WM, Rini BI, Picus J, Gable P, Torti FM, Kaplan E \& Vogelzang NJ 2004 Antiandrogen withdrawal alone or in combination with ketoconazole in androgen-independent prostate cancer patients: a phase III trial (CALGB 9583). Journal of Clinical Oncology 22 1025-1033. (https://doi.org/10.1200/ JCO.2004.06.037)

Smith MR, Saad F, Hussain M, Sternberg CN, Fizazi K, Yamada KS, Kappeler C, Kuss I \& Tombal BF 2018a ARASENS: a phase 3 trial of darolutamide in combination with docetaxel for men with metastatic hormone-sensitive prostate cancer (mHSPC). Journal of Clinical Oncology 36 TPS383. (https://doi.org/10.1200/JCO.2018.36.6_suppl. TPS383)

Smith MR, Saad F, Chowdhury S, Oudard S, Hadaschik BA, Graff JN, Olmos D, Mainwaring PN, Lee JY, Uemura H, et al. 2018b Apalutamide treatment and metastasis-free survival in prostate cancer. New England Journal of Medicine 378 1408-1418.

Smith M, Parker C, Saad F, Miller K, Tombal B, Ng QS, Boegemann M, Matveev V, Piulats JM, Zucca LE, et al. 2019 Addition of radium-223 to abiraterone acetate and prednisone or prednisolone in patients with castration-resistant prostate cancer and bone metastases (ERA 223): a randomised, double-blind, placebo-controlled, phase 3 trial. Lancet: Oncology 20 408-419. (https://doi.org/10.1016/S1470-2045(18)30860-X)

Smith MR, Saad F, Chowdhury S, Oudard S, Hadaschik BA, Graff JN, Olmos D, Mainwaring PN, Lee JY, Uemura H, et al. 2021 Apalutamide and overall survival in prostate cancer. European Urology 79 150-158.

Steinestel J, Luedeke M, Arndt A, Schnoeller TJ, Lennerz JK, Wurm C, Maier C, Cronauer MV, Steinestel K \& Schrader AJ 2019 Detecting predictive androgen receptor modifications in circulating prostate cancer cells. Oncotarget 10 4213-4223. (https://doi.org/10.18632/ oncotarget.3925)

Steinkamp MP, O'Mahony OA, Brogley M, Rehman H, Lapensee EW, Dhanasekaran S, Hofer MD, Kuefer R, Chinnaiyan A, Rubin MA, et al. 2009 Treatment-dependent androgen receptor mutations in prostate cancer exploit multiple mechanisms to evade therapy. Cancer Research 69 4434-4442. (https://doi.org/10.1158/0008-5472.CAN-08-3605)

Sternberg CN, Fizazi K, Saad F, Shore ND, De Giorgi U, Penson DF, Ferreira U, Efstathiou E, Madziarska K, Kolinsky MP, et al. 2020 Enzalutamide and survival in nonmetastatic, castration-resistant prostate cancer. New England Journal of Medicine 382 2197-2206.

Storlie JA, Buckner JC, Wiseman GA, Burch PA, Hartmann LC \& Richardson RL 1995 Prostate specific antigen levels and clinical https://erc.bioscientifica.com

https://doi.org/10.1530/ERC-21-0098 (c) 2021 Society for Endocrinology Published by Bioscientifica Ltd. Printed in Great Britain 
response to low dose dexamethasone for hormone-refractory metastatic prostate carcinoma. Cancer 76 96-100. (https://doi. org/10.1002/1097-0142(19950701)76:1<96::aidcncr2820760114>3.0.co;2-e)

Sugawara T, Baumgart SJ, Nevedomskaya E, Reichert K, Steuber H, Lejeune P, Mumberg D \& Haendler B 2019 Darolutamide is a potent androgen receptor antagonist with strong efficacy in prostate cancer models. International Journal of Cancer 145 1382-1394. (https://doi. org/10.1002/ijc.32242)

Takeda DY, Spisak S, Seo JH, Bell C, O'Connor E, Korthauer K, Ribli D, Csabai I, Solymosi N, Szallasi Z, et al. 2018 A somatically acquired enhancer of the androgen receptor is a noncoding driver in advanced prostate cancer. Cell 174 422.e13-432.e13. (https://doi.org/10.1016/j. cell.2018.05.037)

Tannock IF, de Wit R, Berry WR, Horti J, Pluzanska A, Chi KN, Oudard S, Theodore C, James ND, Turesson I, et al. 2004 Docetaxel plus prednisone or mitoxantrone plus prednisone for advanced prostate cancer. New England Journal of Medicine 351 1502-1512. (https://doi. org/10.1056/NEJMoa040720)

Taplin ME, Bubley GJ, Shuster TD, Frantz ME, Spooner AE, Ogata GK, Keer HN \& Balk SP 1995 Mutation of the androgen-receptor gene in metastatic androgen-independent prostate cancer. New England Journal of Medicine 332 1393-1398. (https://doi.org/10.1056/ NEJM199505253322101)

Taplin ME, Montgomery B, Logothetis CJ, Bubley GJ, Richie JP, Dalkin BL, Sanda MG, Davis JW, Loda M, True LD, et al. 2014 Intense androgen-deprivation therapy with abiraterone acetate plus leuprolide acetate in patients with localized high-risk prostate cancer: results of a randomized phase II neoadjuvant study. Journal of Clinical Oncology 32 3705-3715. (https://doi.org/10.1200/ JCO.2013.53.4578)

Taylor BS, Schultz N, Hieronymus H, Gopalan A, Xiao Y, Carver BS, Arora VK, Kaushik P, Cerami E, Reva B, et al. 2010 Integrative genomic profiling of human prostate cancer. Cancer Cell 18 11-22. (https://doi. org/10.1016/j.ccr.2010.05.026)

Tran C, Ouk S, Clegg NJ, Chen Y, Watson PA, Arora V, Wongvipat J, SmithJones PM, Yoo D, Kwon A, et al. 2009 Development of a secondgeneration antiandrogen for treatment of advanced prostate cancer. Science 324 787-790. (https://doi.org/10.1126/science.1168175)

VanDeusen HR, Ramroop JR, Morel KL, Bae SY, Sheahan AV, Sychev Z, Lau NA, Cheng LC, Tan VM, Li Z, et al. 2020 Targeting RET kinase in neuroendocrine prostate cancer. Molecular Cancer Research 18 1176-1188. (https://doi.org/10.1158/1541-7786.MCR-19-1245)

Visakorpi T, Hyytinen E, Koivisto P, Tanner M, Keinanen R, Palmberg C, Palotie A, Tammela T, Isola J \& Kallioniemi OP 1995 In vivo amplification of the androgen receptor gene and progression of human prostate cancer. Nature Genetics 9 401-406. (https://doi. org/10.1038/ng0495-401)

Viswanathan SR, Ha G, Hoff AM, Wala JA, Carrot-Zhang J, Whelan CW, Haradhvala NJ, Freeman SS, Reed SC, Rhoades J, et al. 2018 Structural alterations driving castration-resistant prostate cancer revealed by linked-read genome sequencing. Cell 174 433.e19-447.e19. (https:// doi.org/10.1016/j.cell.2018.05.036)
Vlachostergios PJ, Puca L \& Beltran H 2017 Emerging variants of castration-resistant prostate cancer. Current Oncology Reports 1932. (https://doi.org/10.1007/s11912-017-0593-6)

von Klot CA, Kuczyk MA \& Merseburger AS 2014a No androgen withdrawal syndrome for enzalutamide: a report of disease dynamics in the postchemotherapy setting. European Urology 65 258-259. (https://doi.org/10.1016/j.eururo.2013.09.036)

von Klot CA, Kramer MW, Boker A, Herrmann TR, Peters I, Kuczyk MA, Ligges U, Gschwend JE, Retz M, Schmid SC, et al. 2014b Is there an anti-androgen withdrawal syndrome for enzalutamide? World Journal of Urology 32 1171-1176. (https://doi.org/10.1007/s00345014-1288-3)

Waltering KK, Helenius MA, Sahu B, Manni V, Linja MJ, Janne OA \& Visakorpi T 2009 Increased expression of androgen receptor sensitizes prostate cancer cells to low levels of androgens. Cancer Research 69 8141-8149. (https://doi.org/10.1158/0008-5472.CAN-09-0919)

Wang Y, Dai B \& Ye DW 2017 Serum testosterone level predicts the effective time of androgen deprivation therapy in metastatic prostate cancer patients. Asian Journal of Andrology 19 178-183. (https://doi. org/10.4103/1008-682X.174856)

Wyatt AW, Azad AA, Volik SV, Annala M, Beja K, McConeghy B, Haegert A, Warner EW, Mo F, Brahmbhatt S, et al. 2016 Genomic alterations in cell-free DNA and enzalutamide resistance in castration-resistant prostate cancer. JAMA Oncology 2 1598-1606. (https://doi.org/10.1001/ jamaoncol.2016.0494)

Xie N, Cheng H, Lin D, Liu L, Yang O, Jia L, Fazli L, Gleave ME, Wang Y, Rennie P, et al. 2015 The expression of glucocorticoid receptor is negatively regulated by active androgen receptor signaling in prostate tumors. International Journal of Cancer 136 E27-E38. (https://doi. org/10.1002/ijc.29147)

Yamada Y \& Beltran H 2021 Clinical and biological features of neuroendocrine prostate cancer. Current Oncology Reports 2315 . (https://doi.org/10.1007/s11912-020-01003-9)

Yoshida T, Kinoshita H, Segawa T, Nakamura E, Inoue T, Shimizu Y, Kamoto T \& Ogawa O 2005 Antiandrogen bicalutamide promotes tumor growth in a novel androgen-dependent prostate cancer xenograft model derived from a bicalutamide-treated patient. Cancer Research $\mathbf{6 5} 9611$ 9616. (https://doi.org/10.1158/0008-5472.CAN-05-0817)

Yuan F, Hankey W, Wu D, Wang H, Somarelli J, Armstrong AJ, Huang J, Chen Z \& Wang Q 2019 Molecular determinants for enzalutamideinduced transcription in prostate cancer. Nucleic Acids Research 47 10104-10114. (https://doi.org/10.1093/nar/gkz790)

Zhou HJ, Yan J, Luo W, Ayala G, Lin SH, Erdem H, Ittmann M, Tsai SY \& Tsai MJ 2005 SRC-3 is required for prostate cancer cell proliferation and survival. Cancer Research 65 7976-7983. (https://doi. org/10.1158/0008-5472.CAN-04-4076)

Zhu ML \& Kyprianou N 2010 Role of androgens and the androgen receptor in epithelial-mesenchymal transition and invasion of prostate cancer cells. FASEB Journal 24 769-777. (https://doi. org/10.1096/fj.09-136994)

Zoubeidi A \& Ghosh PM 2021 Celebrating the 80th anniversary of hormone ablation for prostate cancer. Endocrine-Related Cancer $\mathbf{2 8}$ 1-10. (https://doi.org/10.1530/ERC-21-0192)

Received in final form 8 June 2021

Accepted 15 June 2021

Accepted Manuscript published online 15 June 2021
C) 2021 Society for Endocrinology Published by Bioscientifica Ltd. Printed in Great Britain 